\title{
Hidden nominal structures in Japanese clausal comparatives
}

\author{
Yasutada Sudo
}

Received: 25 May 2010 / Accepted: 26 September 2013 / Published online: 11 July 2014

(C) The Author(s) 2014. This article is published with open access at Springerlink.com

\begin{abstract}
Recent studies of Japanese clausal comparatives have yielded several competing theoretical views of their syntax and semantics that have different implications for the issue of crosslinguistic variation in comparative constructions. This paper aims at contributing to this debate by offering a novel syntactic analysis of Japanese clausal comparatives. The main proposal is that despite their appearance, Japanese clausal comparatives involve a nominal structure whose nominal head is deleted by a syntactic deletion operation, and therefore are underlyingly phrasal comparatives. It is demonstrated that this analysis explains peculiar syntactic and semantic properties of Japanese (seemingly) clausal comparatives, some of which have been unidentified in the previous literature. The proposed account also allows us to dispense with the previously proposed semantic variation specific to degree constructions, and entertain a more conservative view of crosslinguistic variation where the differences between Japanese-type and English-type comparative constructions are solely attributed to their morphosyntactic properties.
\end{abstract}

Keywords Japanese - Comparative construction - Degree nominals · Noun deletion · Semantic variation

\section{Introduction}

1.1 Crosslinguistic variation in comparatives

Recent studies have revealed a considerable degree of crosslinguistic variation in comparative constructions across languages. For example English has two kinds of compar-

\footnotetext{
Y. Sudo $(\bowtie)$

University College London, Chandler House, Room 115,

2 Wakefield St., London WC1N 1PF, UK

e-mail: y.sudo@ucl.ac.uk
} 
ative constructions, at least on the surface, which are often called phrasal and clausal comparatives. In phrasal comparatives, the complement of than is a single phrase, typically a Determiner Phrase (DP), whereas in clausal comparatives, the complement of than is at least as big as a clause (often with ellipsis), as illustrated by (1).
a. Phrasal Comparative
John is smarter [ than Bill ]
b. Clausal Comparative
John is smarter [ than Bill is ]

The fact that pairs like (1) are synonymous naturally leads to the hypothesis that they share underlying syntactic resources, which has been upheld since the 1970s by a number of researchers (Bresnan 1973; Hackl 2000; Lechner 2001, 2004, 2008; Bhatt and Takahashi 2011). Specifically, (1a) can be analyzed as being derived from the same clausal structure as (1b), by deleting everything in the embedded clause except for the DP Bill. As much as it is defended, this hypothesis has also been questioned by a number of authors, at least for some instances of phrasal comparatives (Hankamer 1973; Hoeksema 1983; Pinkal 1990; Kennedy 1999; Pancheva 2006, 2010). As English is not our central concern here, the present paper remains neutral with respect to this long-standing debate, but it is important to remember that it is agreed that underlyingly clausal comparatives are available in English and so English than can directly combine with a clausal structure.

Turning our eyes to other languages, it is noticeable that some languages mark phrasal and clausal comparatives in morphologically distinct ways, unlike English. For example, in Greek, the word for than changes its form in phrasal and clausal comparatives: in a phrasal comparative, the than phrase is expressed as apo followed by an accusative marked DP, while in a clausal comparative, a different word ap'oti is used (Merchant 2009). ${ }^{1}$ Just as in the case of English above, it is possible to construct a synonymous pair in Greek, as shown in (2) (adapted from Merchant 2009, 135f).

(2) Greek

a. Phrasal Comparative

I Maria pezi kithara kalitera apo [ ton Gianni ]

the.NOM Maria plays guitar better than.PHR [ the.ACC Giannis ]

'Maria plays the guitar better than Giannis'

b. Clausal Comparative

I Maria pezi kithara kalitera ap'oti [ pezi kithara o

the.NOM Maria plays guitar better than.CL [ plays guitar the.NOM

Giannis ]

Giannis ]

'Maria plays the guitar better than Giannis does'

\footnotetext{
1 Arguably, ap'oti and apo are morphologically and potentially syntactically related (Merchant 2009, Sabine Iatridou, p.c.), but this is orthogonal to the purposes at hand, and what is important is the morphological distinction between the two types of comparatives.
} 
Russian similarly distinguishes morphologically between phrasal and clausal comparatives. Specifically, Russian phrasal comparatives involve a genitive DP without a word for than, while clausal comparatives involve the instrumental wh-phrase čem with what looks like a clausal complement (Pancheva 2006, 2007).

(3) Russian

a. Phrasal Comparative

Ja lublju Ivana bol’še [ Maši ]

I love Ivan.ACC more [ Masha.GEN ]

'I love Ivan more than Masha'

b. Clausal Comparative

Ja lublju Ivana bol'še čem [ jego ljubit Maša ]

I love Ivan.ACC more what-INSTR [ him loves Masha.NOM ]

'I love Ivan more than Masha does'

(Pancheva 2007)

Hungarian is similar to Russian in this respect, in which phrasal comparatives only involve an adessive DP, without an overt word for than, while an additional word mint appears in clausal comparatives (Wunderlich 2001).

(4) Hungarian

a. Phrasal Comparative

Anna érdekes-ebb volt [ Péter-nél ]

Anna interesting-more was [ Peter-ADESS ]

'Anna was more interesting than Peter'

b. Clausal Comparative

Anna érdekes-ebb, mint [ a-milyen érdekes Péter volt ]

Anna interesting-more than [ REL-what.kind interesting Peter was ]

'Anna is more interesting than Peter was'

(Wunderlich 2001)

Interestingly, in each of these three languages, the clausal option allows radical reduction so that only one DP remains, resulting in a clausal comparative that looks like a phrasal comparative. However, due to the special morphological marking for clausal comparatives, their morphological makeup is different from the corresponding genuine phrasal comparatives. Compare the following sentences with the respective phrasal comparatives above.

Reduced Clausal Comparatives

a. Greek

I Maria pezi kithara kalitera ap'oti [ o Gianni ] the.NOM Maria plays guitar better than.CL [ the.NOM Giannis ]

'Maria plays the guitar better than Giannis' (adapted from Merchant 2009)

b. Russian

Ja ljublju Ivana bol'še čem [ Maša ]

I love Ivan.ACC more what-INSTR [ Masha.NOM ] 
'I love Ivan more than Masha.'

(Inga Vendelin, p.c.)

c. Hungarian

Anna érdekes-ebb, mint [ Péter ]

Anna interesting-more than [Péter]

'Anna is more interesting than Peter'

(Wunderlich 2001)

One way of making sense of these data is that languages like Greek, Russian and Hungarian have two underlyingly distinct comparative constructions that involve different morphosyntactic resources. ${ }^{2}$ According to this view, therefore, phrasal and clausal comparatives are independent constructions with different morphosyntactic properties, at least in some languages. ${ }^{3}$

Interestingly, recent studies on Japanese comparatives (Beck et al. 2004; Kennedy 2009; Oda 2008; Hayashishita 2009; Bhatt and Takahashi 2011; Shimoyama 2012 among others) claim that Japanese clausal comparatives motivate a new type of crosslinguistic variation in comparative constructions, but the exact nature of the variation has been highly contentious and lively disputed. This is the main topic of the present paper, to which we now turn.

\subsection{Japanese clausal comparatives and two types of account}

Japanese appears to have both phrasal and clausal comparatives, as shown in (6). For the reasons explained below, a synonymous pair is hard to construct, unlike in the languages we saw above.

\section{a. Phrasal Comparative}

John-wa [ Mary ]-yori kasikoi

John-TOP [ Mary ]-than smart

'John is smarter than Mary'

b. Clausal Comparative

\section{John-wa [ Mary-ga kitaisita ]-yori kasikoi \\ John-TOP [ Mary-NOM expected ]-than smart \\ 'John is smarter than Mary expected'}

Phrasal comparatives in Japanese only involve a single bare DP as the complement of yori, which is glossed as 'than' throughout this paper. ${ }^{4}$ In clausal comparatives, on the other hand, what precedes yori has a clausal look. In fact, the embedded clause of (6b) can be used as an independent sentence with a pro-dropped object. Also, it

\footnotetext{
2 Merchant (2009) offers an account where Greek phrasal comparatives have underlyingly clausal structures, but does not deny the possibility of genuinely phrasal comparatives in Greek.

${ }^{3}$ Further support for genuinely phrasal comparatives comes from yet another language, Hindi(-Urdu), which is extensively discussed by Bhatt and Takahashi (2011). As their arguments are rather involved, I will not reproduce them here.

4 This is not to imply that yori and than can be given the same analysis in all respects. See the discussion below.
} 
should be remarked that Japanese does not employ an overt morpheme for more or -er, although this fact has no significant role to play in the analysis to be presented below. $^{5}$

As will be discussed in greater detail in the following sections, Japanese clausal comparatives show properties that are not observed with clausal comparatives in English (and other languages like German that are widely assumed to allow underlyingly clausal comparatives). Such observations have led some authors (Kikuchi 1987; Ishii 1991; Hayashishita 2009; Bhatt and Takahashi 2011; Shimoyama 2012) to postulate crosslinguistic variation in clausal comparatives. According to them, Japanese is a language that allows both underlyingly clausal and phrasal comparatives, although Japanese and English clausal comparatives are not identical in all respects, due to more general differences between the two languages. I call accounts of Japanese clausal comparatives along these lines clausal accounts.

On the other hand, Beck et al. (2004), among others, point out that Japanese clausal comparatives exhibit features typically found in complex DPs with relative clauses. Based on this observation, they claim that despite their surface appearance, the complement of yori in a Japanese clausal comparative like (6b) is in fact a DP rather than a complement clause (also Oda 2008; Kennedy 2009). In other words, under Beck et al.'s account, Japanese only has phrasal comparatives, and thus Japanese 'clausal' comparatives do not motivate crosslinguistic variation of clausal comparative constructions. I refer to accounts that prohibit a clausal structure as the complement of yori as phrasal accounts.

The main contribution of the present paper is a novel phrasal account that handles the empirical facts better than its predecessors. Just like Beck et al. (2004), I assume that Japanese clausal comparatives involve a nominal structure, but additionally I propose that its nominal head has undergone syntactic deletion. I argue, furthermore, that this account provides a novel perspective on the crosslinguistic variation in comparative constructions.

Before we proceed, a terminological note is in order. Although it is claimed that Japanese clausal comparatives are in fact underlyingly phrasal comparatives, I continue to refer to them as clausal comparatives when no confusion arises.

The organization of this paper is as follows. In the next section, the details of my new analysis will be spelled out with supporting data. In Sect. 3, I will give empirical motivations for phrasal accounts over clausal accounts by pointing out three common properties between relative clauses and embedded clauses in clausal comparatives. The data in this section partially overlaps with the data raised in Beck et al. (2004) but also contains novel observations. Section 4 is devoted to examination of Kikuchi (1987) arguments for clausal accounts, which are shown to be compatible with the proposed phrasal account. In Sect. 5, I will discuss three peculiar properties of Japanese clausal comparatives that their English counterparts do not exhibit, and how the proposed account deals with them. Section 6 introduces refinements of the proposal in order to circumvent overgeneration problems. Section 7 contains critical reviews of several

\footnotetext{
5 Hayashishita (2009) proposes an alternative theory where this morphological property of Japanese comparatives is given a significant theoretical weight on account of their syntactic and semantic properties. Although this idea is interesting, I will argue in Sect. 7 that his theory is empirically problematic.
} 
major alternative theories. In Sect. 8 I will address the issue of crosslinguistic variation, claiming that my account allows for a view where the relevant aspects of crosslinguistic variation in comparative constructions are located solely in morphosyntax, whereby dispensing with semantic parameters such as the ones proposed by Beck et al. (2004) and Kennedy (2009). Finally, Sect. 9 contains conclusions and discussion of a further issue.

\section{New phrasal account}

2.1 Key data: attributive vs. predicative clausal comparatives

Before delving into the details of the proposal, I would like to start with some data given in (7), which has eluded a theoretical analysis. ${ }^{6}$
a. *John-wa [ Mary-ga yatotta ]-yori kasikoi
John-TOP [ Mary-NOM hired ]-than smart
'(lit.) John is smarter than Mary hired'
b. John-wa [ Mary-ga yatotta ]-yori kasikoi hito-o mituketa John-TOP [ Mary-NOM hired]-than smart person-ACC found 'John found a smarter person than Mary hired'

Notice importantly that the complement of yori looks exactly the same in these two sentences but they sharply contrast in acceptability. This means that there is a difference between predicative cases of clausal comparatives, where the comparative gradable predicate acts as the main predicate of the clause, and attributive cases, where the comparative gradable predicate acts as a modifier of a noun. In other words, in order to account for this contrast, the difference in the matrix structure needs to be referenced. As we will see in detail, this is achieved in my analysis by capitalizing on the licensing conditions of deletion, while no alternative analyses have a principled way to take into account the structure of the matrix clause.

It should also be mentioned here that the contrast between predicative and attributive comparatives obtains only with clausal comparatives, and not with phrasal comparatives, as shown by the following grammatical phrasal comparatives. ${ }^{7}$

$$
\begin{aligned}
& \text { a. John-wa [ Mary-ga yatotta hito ]-yori kasikoi } \\
& \text { John-TOP [ Mary-NOM hired person ]-than smart } \\
& \text { 'John is smarter than the person Mary hired' }
\end{aligned}
$$

\footnotetext{
6 Sudo (2009), which is an earlier version of the present paper written in 2008, raises this contrast as a further issue. Shimoyama (2012) independently observes a similar contrast without accounting for it. The ungrammatical example in (7a) is modeled after a sentence in the handout from her colloquium talk at the Massachusetts Institute of Technology in 2008.

7 A common way of forming phrasal comparatives in Japanese involves the morpheme no, in place of the concrete noun hito in (8). Arguably no has varieties of functions, and its formal syntactic and semantic properties are still poorly understood. To avoid unnecessary complications, I will not discuss examples containing no in this paper. See Beck et al. (2004), Hayashishita (2009), Shimoyama (2012) and works cited therein for discussions on no occurring in comparatives and elsewhere.
} 
b. John-wa [ Mary-ga yatotta hito ]-yori kasikoi hito-o mituketa John-TOP [ Mary-NOM hired person ]-than smart person-ACC found 'John found a smarter person than the person Mary hired'

\subsection{Details of the analysis}

I offer a novel phrasal account that is empirically more adequate than previous accounts, especially with respect to the data in (7) above. Most importantly, with Beck et al. (2004) among others, I assume that the complement of yori can only be a nominal structure (i.e. DP), and cannot be a clause (i.e. CP). In other words, Japanese does not have underlyingly clausal comparatives, and what looks like a clausal complement is actually a relative clause. The innovative feature of my account is the analysis of the nominal structure of the complement of yori. Specifically, I analyze the seemingly clausal look of a Japanese clausal comparative as the result of syntactically deleting the head noun of the complex nominal complement of yori, leaving behind the relative clause. ${ }^{8}$ Furthermore, I claim that predicative clausal comparatives have one underlying structure, while attributive clausal comparatives have two possible structures, which as we will see shortly, is essential in accounting for the contrast in (7).

Let us first illustrate the analysis with predicative clausal comparatives. The idea is that a predicative clausal comparative is derived from a phrasal comparative via deletion of a degree noun that is semantically related to the comparative gradable predicate. Degree nouns are nouns like kasikosa 'smartness' that refer to scalar structures, and generally have corresponding gradable predicates, e.g. the adjective kasikoi 'smart' for kasikosa 'smartness' (I will discuss the relation between gradable predicates and degree nouns in more detail in Sect. 2.3). More concretely, (9a) is assigned the phrasal comparative in (9b) as its underlying structure before deletion, which is also grammatical and semantically identical to it.
a. John-wa [ Mary-ga kitaisita ]-yori kasikoi
John-TOP [ Mary-NOM expected ]-than smart
'John is smarter than Mary expected'
b. John-wa [ Mary-ga kitaisita kasikosa ]-yori kasikoi
John-TOP [ Mary-NOM expected smartness ]-than smart
'John is smarter than the smartness Mary expected'

In (9b) the complement of yori is a complex DP headed by a degree noun kasikosa 'smartness'. I propose that such a degree noun can optionally be deleted in relation to the gradable adjective kasikoi 'smart', giving rise to the surface sequence of (9a). The relevant deletion operation is by assumption licensed in the configuration represented in the tree diagram below. Further details of the proposed head noun deletion are discussed in Sect. 6.2.

\footnotetext{
8 It is therefore crucial for my account that the embedded clause be a genuine relative clause, and not an Internally Headed Relative Clause (IHRC). Incidentally, as Beck et al. (2004) discuss, IHRCs, which have the distributional properties of full DPs, are licit as the complement of yori.
} 
(10)

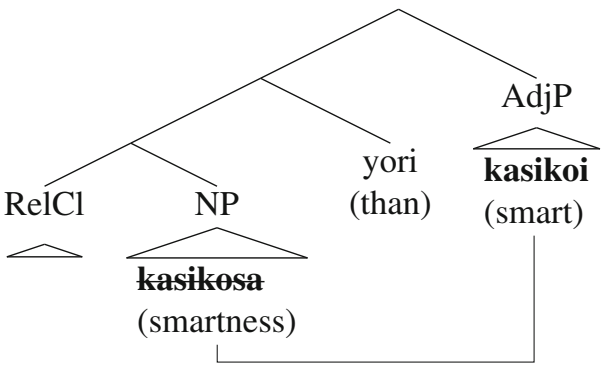

Let us now turn to attributive clausal comparatives. I claim that they can be derived from two different kinds of underlying structures. One of them involves a degree nominal just as in the previous case, while the other involves a concrete noun. For example, the clausal comparative in (11) is assigned the phrasal comparatives in (11a) and (11b) as its possible underlying structures. All three sentences below are grammatical, and also semantically indistinguishable.

John-wa [ Bill-ga katta ]-yori takusan hon-o katta John-TOP [ Bill-NOM bought ]-than many book-ACC bought

'John bought more books than Bill bought'

a. John-wa [ Bill-ga katta ryoo ]-yori takusan hon-o katta John-TOP [ Bill-NOM bought amount ]-than many book-ACC bought 'John bought more books than the amount (of books) that Bill bought'

b. John-wa [ Bill-ga katta hon ]-yori takusan hon-o katta John-TOP [ Bill-NOM bought book ]-than many book-ACC bought 'John bought more books than the books that Bill bought'

The head noun deletion that applies to (11a) is identical in nature to the case of predicative comparatives we have just seen, and the degree noun ryoo 'amount' can be optionally deleted in relation to the gradable adjective takusan 'many'. 9 On the other hand, in (11b), the head noun of the yori phrase, hon 'book', is identical to the head noun modified by the comparative gradable adjective. Notice that both cases result in the same sequence of words after deletion, i.e. (11), and also that there is no noticeable interpretive difference among the three sentences in (11). The relevant parts of the two underlying sentences look as follows. ${ }^{10}$

\footnotetext{
${ }^{9}$ Unlike the pair kasikosa 'smartness'-kasikoi 'smart', ryoo 'amount' and takusan do not bear morphological resemblance to each other. See Sect. 2.3 for more discussion on this.

${ }^{10}$ I assume that the comparative morpheme heads DegP, which is phonologically null in Japanese. These tree diagrams suggest that Deg, rather than A, projects (Abney 1987; Kennedy 1999), but nothing in the proposal here hinges crucially on this assumption.
} 
(12)

a.

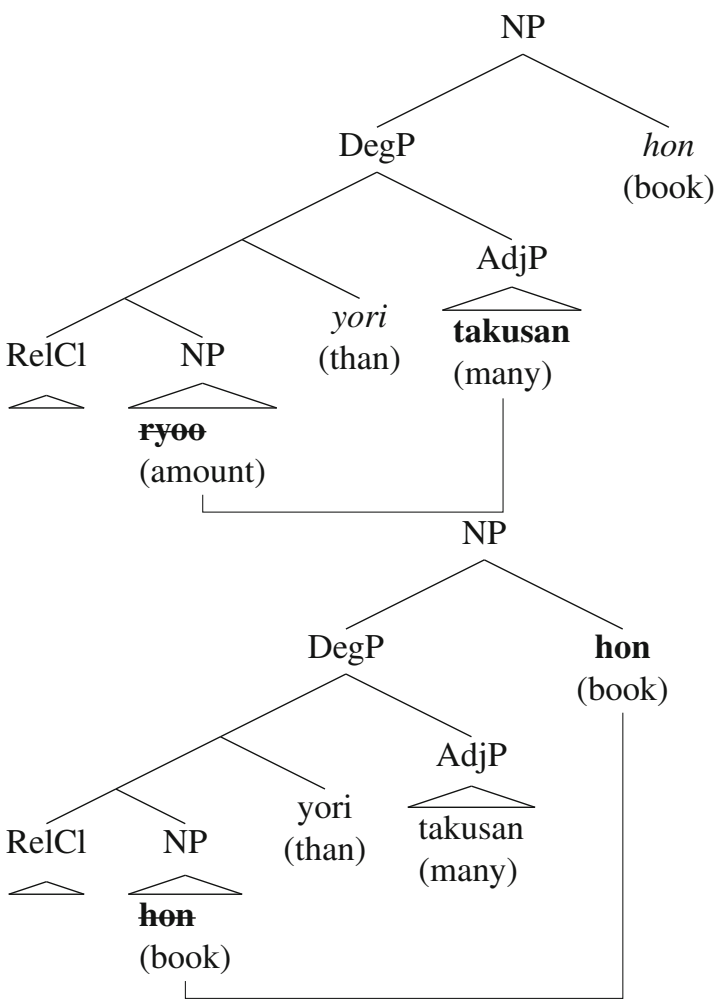

It is crucial for my account that both types of underlying structures-one involving a degree head noun and one involving a non-degree head noun-be syntactically available for all attributive clausal comparatives. This accounts for the fact that in some cases one of the underlying phrasal comparatives is ruled out for semantic/pragmatic reasons, but the corresponding clausal comparative is still acceptable. For instance, the attributive clausal comparative in (13) is grammatical, but one of the underlying phrasal comparatives, namely (13b) which involves a concrete noun, is unacceptable. ${ }^{11}$

(13) John-wa [ Bill-ga manga-o yonda ]-yori takusan shoosetsu-o yonda John-TOP [ Bill-NOM comic-ACC read ]-than many novel-ACC read 'John read more novels than Bill read comics'

a. John-wa [ Bill-ga manga-o yonda ryoo ]-yori takusan John-TOP [ Bill-NOM comic-ACC read amount ]-than many shoosetsu-o yonda novel-ACC read

'John read more novels than the amount of comics that Bill read'

\footnotetext{
11 This example is a case of amount subcomparative, to which I will come back in Sect. 5.
} 
b. *John-wa [ Bill-ga manga-o yonda shoosetsu ]-yori takusan John-TOP [ Bill-NOM comic-ACC read novel ]-than many shoosetsu-o yonda novel-ACC read

'*John read more novels than the novels that Bill read comics'

The embedded clause in (13b) cannot function as a relative clause modifying a nondegree noun shoosetsu 'novel' for obvious reasons, while it can modify a degree noun ryoo 'amount' as in (13a). Under the present account, the grammaticality of the clausal comparative in (13) is attributed to that of the acceptable underlying structure, (13a).

Conversely, there are also instances of attributive clausal comparatives where only the underlying structure with a non-degree noun is grammatical. Such an example typically involves a clause that cannot function as a relative clause modifying a degree nominal, and a case in point is the contrast we saw in (7a) above. Recall that the predicative case of (7a), repeated below as (14a), is ungrammatical. Under the account proposed here, this ungrammaticality is attributed to the ungrammaticality of its underlying structure, namely the phrasal comparative involving a degree nominal kasikosa 'amount' in (14b).

a. *John-wa [ Mary-ga yatotta ]-yori kasikoi

John-TOP [ Mary-NOM hired ]-than smart

'(lit.) John is smarter than Mary hired'

b. *John-wa [ Mary-ga yatotta kasikosa ]-yori kasikoi

John-TOP [ Mary-NOM hired smartness ]-than smart

'(lit.) John is smarter than the smartness Mary hired'

The ungrammaticality of the phrasal comparative (14b) is arguably due to the inability of the relative clause to felicitously modify kasikosa 'smartness' for semantic reasons.

On the other hand, the attributive clausal comparative in (7a) has a grammatical underlying structure. Specifically, although the underlying structure with the degree noun kasikosa 'smartness', i.e. (15a), is ungrammatical for the same reason as (14b), the other option involving a concrete noun, i.e. hito 'person', is perfectly acceptable, as shown in (15b). Notice that (15b) also captures the intended reading of the clausal comparative (15).

(15) John-wa [ Mary-ga yatotta ]-yori kasikoi hito-o mituketa

John-TOP [ Mary-NOM hired ]-than smart person-ACC found

'John found a smarter person than Mary hired'

a. *John-wa [ Mary-ga yatotta kasikosa ]-yori kasikoi hito-o

John-TOP [ Mary-NOM hired smartness ]-than smart person-ACC

mituketa

found

'John found a smarter person than the smartness Mary hired' 
b. John-wa [ Mary-ga yatotta hito ]-yori kasikoi hito-o John-TOP [ Mary-NOM hired person ]-than smart person-ACC mituketa

found

'John found a smarter person than the person Mary hired'

Thus the contrast in (7) is explained under my account by allowing the attributive clausal comparative to have a grammatical source structure that is not available for the predicative clausal comparative.

Before moving on, one prediction of the theory should be mentioned. Notice that the explanation of the unacceptability of (14a) is crucially attributed to the unacceptability of the complex noun phrase in (14b). That is, the relative clause is semantically incompatible with the degree noun kasikosa 'smartness'. The flip side of this explanation is a prediction that both predicative and attributive clausal comparatives in (7) should become acceptable, when a clause that can felicitously modify the relevant degree noun is used instead. This expectation is borne out. For instance, with the relative clause used in (9) which can be a modifier of kasikosa 'smartness', both sentences in (7) become grammatical, as shown in (16).
a. John-wa [ Mary-ga kitaisita ]-yori kasikoi
John-TOP [ Mary-NOM expected ]-than smart
'John is smarter than Mary expected'
b. John-wa [ Mary-ga kitaishita ]-yori kasikoi hito-o mituketa John-TOP [ Mary-NOM hired ]-than smart person-ACC found 'John found a smarter person than Mary expected'

\subsection{Degree nominals}

As we have just seen, deletion of the head noun in the yori phrase plays a crucial role in my phrasal account of Japanese clausal comparatives. As mentioned already, it is assumed that a head noun requires a licensor in order for it to get deleted, namely, either a semantically related gradable predicate like kasikosa 'smartness', or an identical concrete noun like hito 'person'. In the latter case, which is assumed to be only available in attributive clausal comparatives, the licensor and the relevant licensing conditions are relatively clear. That is, the presence of another occurrence of the same noun in the relevant structural configuration is required for the deletion to be licensed. ${ }^{12}$

On the other hand, deletion of a degree noun is less straightforward, as there is no identical degree noun anywhere in the sentence, and thus it appears to be licensed under an incomplete identity. Specifically, we have seen above a case involving the degree nominal kasikosa 'smartness' and the adjective kasikoi 'smart'. Although these two words are not identical, their morphological resemblance is conspicuous, i.e. they share the root kasiko-, and differ only in the suffix. Pairs like kasikosa and kasikoi are

\footnotetext{
12 A similar structural condition needs to be imposed on deletion of degree nouns too. We will come back to this in Sect. 6.
} 
abundant in Japanese and morphologically highly productive. Some more examples are given in (17). ${ }^{13}$
a. omo-sa
'weight'
omo-i
'heavy-PRES'
b. haya-sa
'speed'
haya-i
'fast-PRES'
c. taka-sa
taka-i
'high-PRES'
d. naga-sa
naga-i
'long-PRES'
e. utukusi-sa 'beauty'
utukusi-i 'beautiful-PRES'
f. hanayaka-sa
hanayaka-da'gorgeous-PRES'
g. sizuka-sa
'gorgeousness'
sizuka-da 'quite-PRES'

Capitalizing on these transparent morphological relations, I assume that the identity of the roots is sufficient to license deletion of a degree noun. More specifically, I analyze such noun-adjective pairs as involving the same root but different functional heads, $n$ and $a$ respectively, which determine the category of the resulting complex word (Marantz 2001). Since $-i$ is a tense suffix, I assume that it resides in T rather than $a$, and take $a$ here to be a phonologically null morpheme.

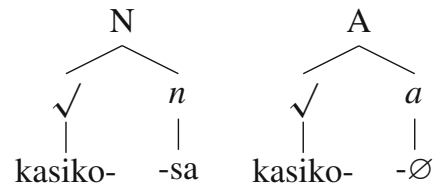

I also assume that such a complex morphological structure is 'visible' to syntax, and deletion of a degree noun is licensed by the corresponding gradable predicate under identity of the roots. The functional heads $n$ and $a$ are not identical, but I assume that this is tolerated, and their suffixal nature requires that they be unpronounced, when the root is deleted (cf. Merchant 2008). ${ }^{14}$ In fact, a similar mismatch of functional heads is known to be possible in English VP-ellipsis, as shown in (19) (Sag 1976; Hardt 1993; Fiengo and May 1994; Johnson 2001; Merchant 2008; see Hardt 1993; Johnson 2001 for deverbal nouns licensing VP-ellipsis).

a. The system can be used by anyone who wants to tse it

b. The janitor must remove the trash whenever it is apparent that it should be removed

(Merchant 2008, p. 169)

In (19b), for instance, the elided material contains the passive morphology - $e d$, although it is absent in the licensor. Assuming that the passive morphology is the head of $v$, the two $v$ Ps involve the same VP but different $v$ 's as depicted in (20).

\footnotetext{
13 The last two pairs involve the so-called 'adjectival verbs' rather than adjectives which differ in the inflectional pattern. I assume that the only difference between adjectives and adjectival verbs is morphological, and not syntactically relevant.

14 It should be mentioned in this connection that Watanabe (2011) suggests the possibility that degree nouns in Japanese can function as adjectives. If this could be maintained in comparatives, the two structures would be completely identical. I thank an anonymous reviewer for bringing Watanabe's work to my attention.
} 
(20)

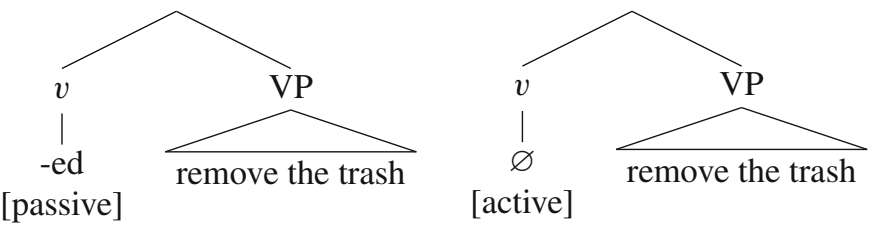

Notice the structural similarity between (18) and (20). That is, deletion targets the complement of the functional head, and the functional head itself, which is morphologically a suffix, does not surface either, despite the fact that there is no identical licensor for the functional head. ${ }^{15}$

However, the above assumption about the licensing condition of degree nominal deletion yields two complications that should be mentioned here. Importantly, however, they are merely complications that arise due to non-transparent morphological relations between degree nouns and gradable predicates, which I assume are essentially morphological accidents in the language, and thus do not threaten the proposed analysis.

First, we saw in the previous subsection an example involving the degree noun ryoo 'amount' that is deleted in relation to the gradable predicate takusan 'many, much'. Although they seem to not share a root at first glance, I submit that they underlyingly do share a common root, and that this is obscured by idiosyncratic spell-out rules that obligatorily apply to them. I denote the root for these words by $\sqrt{\text { amount, }}$ and assume the following spell-out rules. ${ }^{16}$

$$
\begin{aligned}
& \text { a. } \sqrt{\text { amount }}+\mathrm{n} \mapsto \text { ryoo } \\
& \text { b. } \sqrt{\text { amount }}+\mathrm{a} \mapsto \text { takusan }
\end{aligned}
$$

The other complication has to do with the evaluativity of degree nouns. Let us consider the example in (22).

kono heya-wa [ John-ga omotta ]-yori semai

this room-TOP [ John-NOM thought ]-than small

'This room is smaller than John thought'

The adjective here semai 'small' has a transparently morphologically related degree noun semasa 'smallness'. However a wrong meaning would be predicted for (22) if the only possible underling sentence were (23).

kono heya-wa [ John-ga omotta semasa ]-yori semai

this room-TOP [ John-NOM thought smallness ]-than small

'(lit.) This room is smaller than the smallness John thought it had'

\footnotetext{
15 Although there are similarities, English VP-ellipsis and the proposed deletion of nouns/roots show different licensing properties. See Sect. 6.

16 Takusan-sa 'abundance' is also a well-formed degree noun, which evidently has a more morphologically transparent relation with the gradable predicate takusan 'many, much'. However, due to its evaluativity (i.e. it implies that the denoted degree is above the contextually relevant standard), it will fail to account for the fact that the clausal comparative in question is not associated with this implication. See the discussion immediately below.
} 
Although perfectly grammatical, (23) necessarily implies that John thought the room was small, an inference that (22) does not necessarily have. I claim that in this case, the underlying structure can be one that involves a neutral noun hirosa 'size', given in (24).

\section{kono heya-wa [ John-ga omotta hirosa ]-yori semai this room-TOP [ John-NOM thought size ]-than small \\ '(lit.) This room is smaller than the size John thought it had'}

For the purposes of licensing the noun deletion in this example, I adopt the idea put forward by Büring $(2007,2009)$ that negative adjectives are syntactically complex and consist of a positive adjective and a negation (but see Heim 2008 for some complications). For example, sema $(-i)$ has a structure in (25) involving a negation represented here as $\neg$, and the whole structure gets pronounced as sema- by a spell-out rule.

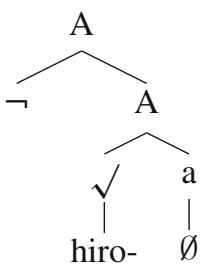

This structure licenses the deletion of the noun hirosa 'size' in (24), since there is a shared root. As a result, the surface string in (22) ensues. ${ }^{17,18}$

\footnotetext{
17 I have emphasized that the identity of the morphological roots is necessary for deletion of a degree noun. This is in line with the general idea that deletion operations require a notion of morphosyntactic identity between the licensor and the licensee. Notice however that each pair of a degree noun and a gradable predicate also involves a (partial) semantic identity in the sense that the same scale is referred to, e.g. the scale of smartness in the case of kasikosa 'smartness' and kasikoi 'smart'. One way to directly connect these morphological and semantic considerations is to assume that the root denotes a scale, and the functional heads like $a$ and $n$ turn it into predicative meanings. Since pursuing this idea further would take us too far afield and it is not crucial for the syntactic account I advocate here, I leave this possibility open for future research.

18 An anonymous reviewer raises the following pair of examples, whose contrast is at first blush unexpected under my account (it appears that (ib) is not perfectly acceptable, but the contrast is real at least for some speakers).
}
a. *John-wa [ Mary-ga hakari-ni noseta ]-yori omoi John-TOP [ Mary-NOM scale-on put ]-than heavy
'(lit.) John is heavier than Mary put on the scale.

b. ?John-wa [ Mary-ga hakari-ni noseta omosa ]-yori omoi John-TOP [ Mary-NOM scale-on put heaviness ]-than heavy '(lit.) John is heavier than the heaviness that Mary put on the scale.

However, notice that the noun omosa in (ib) is behaving as an individual denoting noun, by virtue of the fact that it serves as the object of noseta 'put', whose semantics requires its object to be a concrete individual (which might well be the cause of the degraded status of (ib)). I assume that deletion of the individualdenoting use of a noun like omosa, if any, is not licensed by omoi, although spelling this out in detail requires more assumptions to be made, which I leave for future research. See the previous footnote for related points. 


\section{Parallelism with relative clauses}

As we saw in the previous section, the account of Japanese clausal comparatives put forward in this paper is a phrasal account, according to which the complement of yori can only be a DP, and the embedded clause in a Japanese clausal comparative is in fact a relative clause stranded by head noun deletion, rather than a complement clause. This is a possibility, as (Modern) Japanese does not morphologically distinguish relative clauses from complement clauses in most cases (we will see some exceptions immediately below; cf. Murasugi 1991; Kaplan and Whitman 1995). For example, the relative clause in (26a) does not involve any morphology indicating that it is a relative clause in comparison to a simple transitive sentence in (26b), or a complement transitive clause in (26c).

a. Relative Clause

[ John-ga yonda ] hon

[ John-NOM read ] book

'the book that John read'

b. Transitive Clause

John-ga hon-o yonda

John-NOM book-ACC read

'John read a book'

c. Embedded Transitive Clause

John-ga hon-o yonda to Mary-wa omotteiru

John-NOM book-ACC read C Mary-TOP thinks

'Mary thinks that John read a book'

Despite the lack of a morphological marking for relative clauses in these cases, there still are several language-specific features that distinguish relative clauses from other kinds of clauses. For the rest of this section, I will show that the embedded clause in a Japanese clausal comparative exhibits morphological, syntactic and semantic properties that are typically observed with relative clauses. This fact lends support to phrasal accounts like the one proposed here, and at the same time poses a challenge for clausal accounts.

\subsection{Morphological evidence: adnominal inflection}

We have just seen that Japanese relative clauses look exactly like complement clauses with most predicates, due to the lack of a morphological marking distinguishing relative clauses from complement clauses. However, there are a few exceptions to this generalization, namely certain adjectives (e.g. ooki- 'big', tiisa- 'small') and the copula $-d a$ in the present tense, which do take different forms in relative clauses and non-relative clauses, as illustrated by the examples below. The adnominal inflection is optional for the adjectives but obligatory for the copula. 
(27)

\section{Adjective}

a. koe-ga ooki-\{i, *na $\}$ voice-NOM big - $-\{$ PRES, ADNOM $\}$

'The voice is loud'

b. ooki $-\{i, \quad$ na $\}$ koe big - $\{$ PRES, ADNOM $\}$ voice 'a loud voice'

(28) Copula

a. koe-ga kirei $-\{$ da, $*$ na $\}$ voice-NOM beautiful -\{COP.FIN, *COP.ADNOM $\}$

'The voice is beautiful'

b. kirei $-\{*$ da, na $\} \quad$ koe beautiful $-\left\{{ }^{*}\right.$ COP.FIN, COP.ADNOM $\}$ voice 'a beautiful voice'

In the following discussion, I focus on the copula $-d a$, but the exact same argument can be made with the adjectives.

In matrix and complement clauses, the copula in the present tense obligatorily appears as $-d a$ and cannot take the adnominal form -na as shown in (29).

[ sono ryuusi-wa keesoku kanoo $-\{$ da, *na $\}$ to ]

[ that particle-TOP measurement possibility $-\left\{\right.$ COP.FIN, ${ }^{*}$ COP.ADNOM $\} \mathrm{C}$ ]

(John-wa omotteiru)

(John-TOP think)

'(John thinks that) that particle is measurable'

In relative clauses, on the other hand, the copula must be realized as -na.

sore-wa [ keesoku kanoo $-\left\{\begin{array}{lll}* \text { da, } & \text { na }\} \quad \text { ryuusi-da }\end{array}\right.$

that-TOP [ measurement possibility $-\left\{{ }^{*}\right.$ COP.FIN, COP.ADNOM $\left.\}\right]$ particle-COP

'That is a measurable particle'

Crucially, when used as the main predicate in the embedded clause in a clausal comparative, the copula has to be in the adnominal form, as illustrated in (31). ${ }^{19}$

kono ryuusi-wa [ kono kikai-de keesoku kanoo

this particle-TOP [ this machine-with measurement possibility

$-\{*$ da, na $\quad]$-yori tiisai

$-\left\{*^{*}\right.$ COP.FIN, COP.ADNOM $\}$ ]-than small

'This particle is smaller than this machine can measure'

\footnotetext{
19 An anonymous reviewer reports that (31) is ungrammatical for his/her consultants with both forms. As my informants, including myself, judge the sentence as perfectly acceptable, this could be inter-speaker or potentially inter-dialectal variation, but it is beyond the scope of this paper to elucidate exactly how the two groups of speakers differ.
} 
Under the phrasal account put forward here, this state of affairs is expected, as there is in fact a nominal following the copula in the underlying phrasal comparative. More specifically (31) is derived from the following phrasal comparative by deleting the head noun ookisa 'size'. Crucially, the copula must take the adnominal form here too.

$$
\begin{aligned}
& \text { kono ryuusi-wa [ kono kikai-de keesoku kanoo } \\
& \text { this particle-TOP [ this machine-with measurement possibility } \\
& -\{* \text { da, na }\} \text { ookisa ]-yori tiisai } \\
& -\{* \text { COP.FIN, COP.ADNOM }\} \text { size ]-than small }
\end{aligned}
$$

'This particle is smaller than the size that this machine can measure'

\subsection{Syntactic evidence: $g a /$ no-conversion}

Secondly, subjects in Japanese generally bear the nominative marker - $g a$ when they are not topics, but in relative clauses, they can optionally appear with the genitive marker -no instead, a phenomenon often referred to as ga/no-conversion. Crucially, ga/no-conversion is generally unattested in non-relative clauses (Harada 1971; Ochi 2001; Watanabe 1996; but see Hiraiwa 2002; Maki and Uchibori 2008 for complications). ${ }^{20}$ The following examples show that genitive subjects are not licensed in matrix clauses, declarative complements and interrogative complements, but are fine in relative clauses.

a. Matrix Clause

John $-\{*$ no, ga, wa $\}$ hon-o kaita

John $-\left\{*^{*}\right.$ GEN, NOM, TOP $\}$ book-ACC wrote

'John wrote a book'

b. Declarative Complement

Mary-wa [ John $-\left\{*^{*}\right.$ no, ga $\}$ hon-o kaita to ] omotteiru

Mary-TOP [ John -\{GEN, NOM $\}$ book-ACC wrote C ] think

'Mary thinks that John wrote a book'

c. Interrogative Complement

Mary-wa [ John - $\{*$ no, ga $\}$ hon-o kaita ka ] siritagatteiru

Mary-TOP [ John $-\left\{*^{*}\right.$ GEN, NOM $\}$ book-ACC wrote C ] wonder

'Mary wonders whether John wrote a book'

d. Relative Clause

Mary-wa [ John-\{no, ga $\}$ kaita ] hon-o yonda

Mary-TOP [ John -\{GEN, NOM $\}$ wrote ] book-ACC read

'Mary read the book that John wrote'

\footnotetext{
20 In addition to this syntactic constraint, there are known to be several constraints on $\mathrm{ga} / \mathrm{no}$-conversion, some of which appear to be violable for some speakers. Due to these constraints, it is expected that not all instances of clausal comparatives license genitive subjects. As two anonymous reviewers independently pointed out, this prediction is generally borne out. Since this aspect of the phenomenon is orthogonal to the point being made here, I will not discuss relevant examples here. The interested reader is referred to the works cited above, and also to Nambu (2007) for a quantitive study.
} 
As Beck et al. (2004, p. 322) observe (also Hiraiwa 2002; Watanabe 1996), the subjects of clausal comparatives in Japanese can undergo ga/no-conversion, as illustrated in (34).

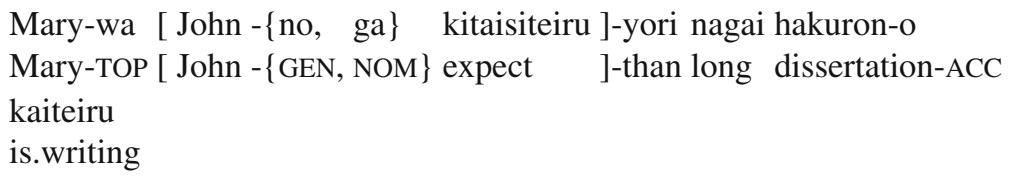

'Mary is writing a longer dissertation than John expects'

This data again suggests that the embedded clause of (34) is in fact a relative clause, which is in accord with my analysis. Specifically, (34) is assigned the following two possible underlying phrasal comparatives. In both cases, the genitive marking on the subject is grammatical.

a. Mary-wa [ John -\{no, ga $\}$ kitaisiteiru nagasa ]-yori nagai Mary-TOP [ John -\{GEN, NOM $\}$ expect length ]-than long hakuron-o kaiteiru dissertation-ACC is.writing

'Mary is writing a longer dissertation than the length John expects'

b. Mary-wa [ John-\{no, ga $\}$ kitaisiteiru hakuron ]-yori nagai Mary-TOP [ John -\{GEN, NOM $\}$ expect dissertation ]-than long hakuron-o kaiteiru dissertation-ACC is.writing

'Mary is writing a longer dissertation than the dissertation John expects'

\subsection{Semantic evidence: statives in the simple present tense}

Our third evidence is semantic in nature. In Japanese, non-agentive or non-causative change-of-state predicates in the simple present tense such as omo- $u$ 'think' cannot receive a stative reading, but only a change-of-state reading such as 'come to think', and in order to obtain the stative reading, a progressive morpheme must be used (cf. Ogawa 2004). ${ }^{21}$ However, relative clauses are an exception to this restriction. For example, in the non-relative clauses in (36a)-(36c), omo- $u$ 'think' is obligatorily read as a change-of-state predicate (similar to 'come to think'), but in the relative clause in (36d), it may optionally receive a stative reading.

\section{a. Matrix Clause}

John-wa [ sore-ga hukanoo-da to ] omo-u

John-TOP [ that-NOM impossible-COP C ] think-PRES

'John \{comes to think, *thinks $\}$ that it is impossible'

\footnotetext{
21 This generalization only holds with a third person subject. In the declarative mood, first person subjects license the stative reading and in the interrogative mood, second person subjects do, even in the simple present tense. Thus counter-examples to the stated generalization may be found with first or second person subjects. A theoretical explanation of this restriction is beyond the scope of the present paper.
} 
b. Declarative Complement

Bill-wa [ John-ga [ sore-ga hukanoo-da to ] omo-u to ]
Bill-TOP [ John-NOM [ that-NOM impossible-COP C ] think-PRES C ]
sinziteiru
believe

'Bill believes that John \{comes to think, *thinks \} that it is impossible'

c. Interrogative Complement
Bill-wa [ John-ga [ sore-ga hukanoo-da to ] omo-u ka ]
Bill-TOP [ John-NOM [ that-NOM impossible-COP C ] know-PRES Q ] sitteiru
know

'Bill knows if John \{comes to think, *thinks $\}$ that it is impossible'

d. Relative Clause

Mary-wa [ [ sore-ga hukanoo-da to ] omo-u ] otoko-ni atta Mary-TOP [ [ that-NOM impossible-COP C ] believe-PRES ] man-DAT met

'Mary met a man who \{thinks, comes to think that it is impossible'

Just as relative clauses, embedded clauses in clausal comparatives license stative readings, as shown in (37).
Bill-wa [ John-ga omo-u ] -yori kasikoi
Bill-TOP [ John-NOM think-PRES ] -than smart
'Bill is smarter than John \{thinks, comes to think\}'

This data again supports a phrasal account where Japanese clausal comparatives in fact involve nominal complements rather than clausal complements. Specifically, under the present account, the sentence from which (37) is derived involves a relative clause where the predicate omo- $u$ does have a stative reading. ${ }^{22}$

\footnotetext{
22 It might come as a surprise that the complex nominal in (38) has the reading indicated in the English translation. I take it to be suggesting that Japanese omo- and English think are not completely identical, and the former can be used transitively. However, for reasons that I do not fully understand, the relevant transitive use of omo- seems to be restricted to relative clauses. For instance, omo- occurring in the relative clause in (ib) has a reading it does not have in (ia).
}
a. John-wa paatii-ni ita hito-o omotta John-TOP party-LOC was person-ACC thought
'John thought (affectionately) about the person who was at the party'
b. John-ga omotta hito-ga paatii-ni ita
John-NOM thought person-NOM party-LOC was
'The person John thought (affectionately) about was at the party'
'The person John thought would be there was at the party'

What is important for our purposes here is only the parallelism between (37) and (38), and I leave this observation unexplained here. 


\author{
Bill-wa [ John-ga omo-u kasikosa ] -yori kasikoi \\ Bill-TOP [ John-NOM think-PRES smartness ] -than smart \\ 'Bill is smarter than the smartness that John \{thinks, comes to think\} Bill has'
}

\title{
3.4 Section summary
}

In this section, we saw three kinds of empirical data showing morphological, syntactic and semantic commonalities between relative clauses and clausal comparatives in Japanese. The first morphological evidence is the strongest among the three, as it shows that the embedded clauses of Japanese clausal comparatives are always relative clauses, whereas the other two only imply the possibility of the relative clause parsing.

\section{Putative arguments for clausal accounts}

In this section, I will review arguments for clausal accounts raised by Kikuchi (1987), and show that they are in fact compatible with my phrasal account. Other proponents of clausal accounts such as Hayashishita (2009) and Shimoyama (2012) point out empirical problems for Beck et al.'s (2004) phrasal analysis and pursue a clausal analysis as an alternative, but their empirical arguments are specifically against Beck et al. (2004) and cannot necessarily be taken to motivate a clausal analysis, as Shimoyama (2012) explicitly acknowledges. Similarly, Bhatt Takahashi (2011) support a clausal analysis, but their data only shows that Japanese phrasal and clausal comparatives involve different underlying structures, and are not incompatible with an analysis where clausal comparatives have phrasal sources. ${ }^{23}$ For this reason, I focus on Kikuchi's (1987)

23 Although not a direct argument for a clausal analysis, Bhatt and Takahashi (2011) raises interesting examples where multiple DPs appear as the complement of -yori. Many of my informants, including myself, did not find (i) perfectly grammatical, but it is arguably not ungrammatical, as mentioned by Bhatt and Takahashi (2011, fn.20) (I thank an anonymous reviewer for reminding me of this data).

(i) [ Taroo-ga Tokyo-de ]-yori Jiro-ga Kyooto-de ooku-no hito-ni atta

[ Taro-NOM Tokyp-in ]-than Jiro-NOM Kyoto-in many people-DAT met

'Jiro met more people in Kyoto than Taro in Tokyo'

(Bhatt and Takahashi 2011, p. 608)

Under my account, (i) has (ii) as its underlying structures.

(ii) a. [ Taroo-ga Tokyo-de atta ninzuu ]-yori Jiro-ga Kyooto-de ooku-no hito-ni atta [ Taro-NOM Tokyp-in met number ]-than Jiro-NOM Kyoto-in many people-DAT met 'Jiro met more people in Kyoto than the number of people that Taro met in Tokyo'

b. [ Taroo-ga Tokyo-de atta hito ]-yori Jiro-ga Kyooto-de ooku-no hito-ni atta [ Taro-NOM Tokyp-in met person ]-than Jiro-NOM Kyoto-in many people-DAT met 'Jiro met more people in Kyoto than the people Taro met in Tokyo'

In order to derive (i) from one of these sentences, deletion of the embedded predicate atta 'met', in addition to deletion of the head noun, is necessary. Notice that under my account, the latter must be a necessary condition for the former, so that the version of (i) with the head noun but not atta becomes ungrammatical. I leave investigation of how predicate deletion interacts with the proposed deletion of head nouns for future research. 
counter-argument against phrasal analyses here, leaving it to the interested reader to apply my analysis to the data raised by the other proponents of clausal analyses.

Observing that Japanese clausal comparatives exhibit typical properties of A'movement, Kikuchi (1987) concludes that an operator movement is involved in Japanese clausal comparatives. More specifically, he identifies the following properties for Japanese clausal comparatives.
a. Obligatory presence of an empty category
b. Unboundedness
c. Island sensitivity
d. Parasitic gap licensing
e. Weak Cross Over effects
f. Specificity Condition
g. Ban on possessor raising

I will not review Kikuchi's empirical evidence here, but I concur with him that his data compellingly suggests the existence of an operator movement in Japanese clausal comparatives. Assuming that the gap in a Japanese clausal comparative is the trace of the null operator, Kikuchi suggests a clausal account that is depicted in (40).

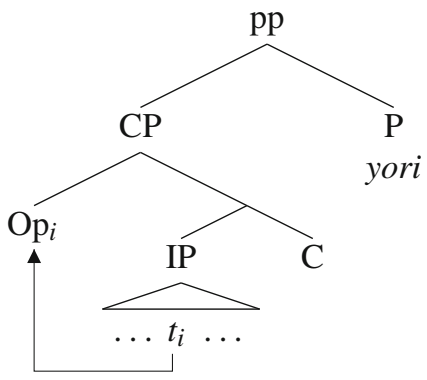

Thus, according to his account, yori directly combines with a CP.

However, it is evident that the presence of an operator movement per se does not necessarily motivate a clausal account, because relative clauses arguably involve an operator movement as well, and hence it is not surprising to find the properties listed in (39) under a phrasal account too. Being aware of this alternative possibility, Kikuchi (1987) raises two counter-arguments against it. One is the observation that overt resumptive pronouns are unavailable in clausal comparatives, unlike in relative clauses, as illustrated by the following pair of a clausal comparative and a relative clause.

a. John-wa [ [ Tom-ga (*sorera-o) tabeta koto ]-ga akirakana ]-yori John-TOP [ [ Tom-NOM (these-ACC) ate fact ]-NOM clear ]-than takusan imo-o tabeta many potato-ACC ate 'John ate more potatoes than the potatoes such that the fact that Tom ate them is clear' 
b. [ [ Tom-ga (?sorera-o) tabeta koto ]-ga akirakana ] takusan-no [ [ Tom-NOM (these-ACC) ate fact ]-NOM clear ] many-GEN imo

potato

'The many potatoes such that the fact that Tom ate them is clear'

(adapted from Kikuchi 1987, p. 50)

However, this contrast is not necessarily problematic for my phrasal account. Under my analysis, (41a) has the following two source structures, both of which do not allow a resumptive pronoun.

a. John-wa [ [ Tom-ga (*sorera-o) tabeta koto ]-ga akirakana ryoo John-TOP [ [ Tom-NOM (these-ACC) ate fact ]-NOM clear amount ]-yori takusan imo-o tabeta

]-than many potato-ACC ate

'John ate more potatoes than the amount such that the fact that Tom ate that amount is clear'

b. John-wa [ [ Tom-ga (*sorera-o) tabeta koto ]-ga akirakana imo John-TOP [ [ Tom-NOM (these-ACC) ate fact ]-NOM clear potato ]-yori takusan imo-o tabeta ]-than many potato-ACC ate

'John ate more potatoes than the potatoes such that the fact that Tom ate them is clear'

Admittedly the fact that (42b) does not allow the pronoun/demonstrative sorera is surprising in light of the grammaticality of (41b). In fact, (41b) and the complex noun in (42b) minimally contrast in acceptability outside of comparatives as well, as shown below.

a. [ [ Tom-ga (?sorera-o) tabeta koto ]-ga akirakana ] takusan-no

[ [ Tom-NOM (these-ACC) ate fact ]-NOM clear ] many-GEN imo

potato

'The many potatoes such that the fact that Tom ate them is clear'

b. [ [ Tom-ga (*sorera-o) tabeta koto ]-ga akirakana ] imo

[ [ Tom-NOM (these-ACC) ate fact ]-NOM clear ] potato

'The potatoes such that the fact that Tom ate them is clear'

It is beyond the scope of the present paper to give a formal account of this contrast, but crucially, the contrast in (43) implies that the data that Kikuchi raises is not incompatible with my phrasal account, and in fact is predicted by it.

Another argument against phrasal accounts that Kikuchi discusses is the following contrast between a phrasal comparative with no and the corresponding clausal comparative in (44).

(44) kono heya-ni iru syuuzin-tati-ni tuite ie ba, this room-in be prisoner-PL-DAT about say if, 
[ okasita tumi-ga omoi *(no)]-yori ooku-no

[ committed crime-NOM serious *(NO) ]-than many-GEN

keehanzai-syuuzin-ga iru

minor.offence-prisoners are

'As for the prisoners in this room, there are more prisoners who committed minor offences than ones that committed serious crimes'

(adapted from Kikuchi 1987, p. 52)

Assuming that the embedded clause with no is a relative clause, Kikuchi claims that this contrast shows a difference between relative clauses and comparative clauses.

However, the ungrammaticality of the clausal option here follows from my phrasal analysis, according to which the two source structures for the clausal comparative are the following.

a. \#[ okasita tumi-ga omoi kazu ]-yori ooku-no keehanzai [ committed crime-NOM serious number ]-than many-GEN minor.offence syuuzin-ga iru prisoners are

b. \#[ okasita tumi-ga omoi keehanzai syuuzin ]-yori ooku-no [ committed crime-NOM serious minor.offence prisoners ]-than keehanzai syuuzin-ga iru many-GEN minor.offence prisoners are

The reason why the structure in (45a) is not acceptable is not entirely clear to me, but essentially the same anomaly is observed with a predicative sentence like (46a), which under my analysis, has the same yori phrase as (45a). Compare this also to a similar but perfectly acceptable amount predicative comparative, (46b). This contrast suggests that there is something wrong with the relative clause modification in (45a).

a. \#keehanzai-syuuzin-wa [ okasita tumi-ga omoi (kazu) minor.offence-prisoner-TOP [ committed crime-NOM serious (number)

]-yori ooi ]-than many

b. keehanzai-syuuzin-wa [ John-ga yosooshita (kazu) ]-yori minor.offence-prisoner-TOP [ John-NOM estimated (number)]-than ooi many

'There are more minor offence prisoners than John estimated'

As in the previous case, the explanation of the unacceptability is yet to be worked out, but it is crucial for our purposes here that (45a) is not a felicitous source structure for (44). Furthermore, the other source structure with a concrete noun (45b) is also infelicitous, due to the obvious semantic clash between the noun keehanzai syuuzin 'prisoners who committed minor offences' and the relative clause okasita tumi-ga omoi 'who committed serious crimes'. Moreover, if the noun here is replaced with a 
simpler noun that is compatible with the relative clause, both (44) and (45b) become perfectly acceptable with identical interpretations, as predicted under my account.

a. [ okasita tumi-ga omoi ]-yori ooku-no [okasita [ committed crime-NOM serious ]-than many-GEN [ committed tumi-ga karui ] syuuzin-ga iru crime-NOM minor ] prisoners are

b. [ okasita tumi-ga omoi syuuzin ]-yori ooku-no [okasita [ committed crime-NOM serious prisoner ]-than many-GEN [ committed tumi-ga karui ] syuuzin-ga iru crime-NOM minor ] prisoners are

'There are more prisoners that committed minor crimes than prisoners that committed serious ones.'

Therefore, again, the contrast in (44) is not a problem for my phrasal account, although it remains to be accounted for why some of the unacceptable examples above are unacceptable. $^{24}$

\section{Three peculiar properties of Japanese clausal comparatives}

There are a number of syntactic and semantic theories of English clausal comparatives, but generally Japanese clausal comparatives cannot be analyzed on a par with their English counterparts, as they exhibit certain properties that are not observed with English clausal comparatives. ${ }^{25}$ In this section, I examine three such properties, and show that they straightforwardly follow under my account.

\subsection{Ban on simple clausal comparatives}

First, simple clausal comparatives such as (48), below, are ungrammatical in the intended reading unlike in English. ${ }^{26}$

\footnotetext{
${ }^{24}$ Notice that my account crucially assumes for (47b) that its yori clause contains the noun syuuzin to the exclusion of the relative clause modifying the licensor occurrence of this noun in the matrix clause, but for (45b), the entire compound keehanzai-syuuzin needs to be in the yori clause, which causes the semantic clash. This follows if the noun deletion operation can skip the relative clause modification but cannot look into a compound noun. I believe this assumption is not outlandish.

25 I do not discuss analyses of English clausal comparatives, which are largely orthogonal to Japanese clausal comparatives for this reason. The literature on the syntax and semantics of English comparatives is exceptionally rich. See for example Bhatt and Takahashi (2011), Cresswell (1976), von Stechow (1984), Hackl (2000), Heim (1985, 2006), Kennedy (1999), Klein (1991), Lechner (2001), Rullmann (1995) and Beck (2010).

${ }^{26}$ Kawahara (2009) claims that (48) without deletion is relatively acceptable under the 'comparison of deviance' reading, which compares the degree to which John's smartness deviates from the standard and the degree to which Bill's smartness does. This reading, which is arguably not the most prominent one, seems to be facilitated to some extent by presuppositional particles such as -mo 'also, even' and motto.
}

(i) ??John-wa [ Bill-ga kasikoi ]-yori(-mo) (motto) kasikoi John-TOP [ Bill-NOM (smart) ]-than(-FOC) (even.more) smart

'John is even smarter than Bill is' 


$$
\begin{aligned}
& \text { *John-wa [ Bill-ga (kasikoi) ]-yori kasikoi } \\
& \text { John-TOP [ Bill-NOM (smart) ]-than smart } \\
& \text { '(intended) John is smarter than Bill is' }
\end{aligned}
$$

In English the embedded occurrence of the degree predicate is obligatorily deleted, but the deletion of the predicate does not save the sentence in Japanese.

The ungrammaticality of (48) is straightforwardly explained under the account put forward here, as its source structure in (49) is ungrammatical.
*John-wa [ Bill-ga kasikoi kasikosa ]-yori kasikoi
John-TOP [ Bill-NOM smart smartness ]-than smart
'(intended) John is smarter than the smartness Bill is'

That is, the relative clause is not an appropriate predicate for a degree nominal like kasikosa 'smartness' (but see fn. 26 for a potential complication).

\subsection{Ban on subcomparatives}

Secondly, in Japanese not only attributive but also predicative subcomparatives are generally ungrammatical, as discussed by many authors (Snyder et al. 1994; Beck et al. 2004; Bhatt and Takahashi 2011). Two such examples are given in (50). Notice that the English translation of (50b) is also ungrammatical. ${ }^{27}$

\section{a. Predicative Subcomparative}

*kono tana-wa [ ano doa-ga takai ]-yori nagai

this shelf-TOP [ that door-NOM tall ]-than long

'This shelf is longer than that door is tall'

b. Attributive Subcomparative

*John-wa [ Mary-ga manga-o yonda ]-yori omosiroi shoosetu-o John-TOP [ Mary-NOM comic-ACC read]-than interesting novel-ACC yonda

read

‘*John read a more interesting novel than Mary read a comic'

\section{Footnote 26 continued}

As the grammatical status of this reading is not entirely clear, I will put it aside in this paper. Nonetheless it should be noted that the underlying structure that my account assigns to (i) seems to have a similar hazy grammatical status with the identical reading.

(ii) ??John-wa [ Bill-ga kasikoi kasikosa ]-yori(-mo) (motto) kasikoi John-TOP [ Bill-NOM (smart) smartness ]-than(-FOC) (even.more) smart

' (lit.) John is even smarter than the smartness that Bill is smart'

27 The ungrammaticality of attributive subcomparatives is not universal, as observed by Kennedy and Merchant (2000). According to them, languages where the Left Branch Condition can be violated, e.g. Czech and Polish, permit attributive subcomparatives, unlike languages where the Left Branch Condition is active, such as English, Greek and Bulgarian. This generalization is not directly relevant here, as my explanation of the ungrammaticality of attributive subcomparatives in Japanese is distinct in nature from the analysis of attributive subcomparatives in English. 
The only possible kind of subcomparative in Japanese is amount subcomparatives such as the following.

\section{Amount Subcomparative}

Mary-wa [ John-ga manga-o yonda ]-yori takusan hon-o yonda Mary-TOP [ John-NOM comic-ACC read ]-than many book-ACC read

'Mary read more books than John read comics'

The above observation is straightforwardly explained under my account, as the judgments of the sentences are exactly parallel to the judgments of their underlying phrasal comparatives. Let us go through the three cases one by one. Firstly, the predicative subcomparative in (52a) is assigned (52b) as its underlying structure, which is ungrammatical.

\section{Predicative Subcomparative}

a. *kono tana-wa [ ano doa-ga takai ]-yori nagai this shelf-TOP [ that door-NOM tall ]-than long 'This shelf is longer than that door is tall'

b. *kono tana-wa [ ano doa-ga takai nagasa ]-yori nagai this shelf-TOP [ that door-NOM tall length ]-than long '*This shelf is longer than the length that door is tall'

The source structure in (52b) is doubly ungrammatical in the sense that the relative clause cannot modify a degree nominal like nagasa 'length', and also that the meaning would not be the intended reading of (52a). Thus, (52a) is correctly predicted to be ungrammatical.

The attributive subcomparative in (53) has two possible underlying structures under my analysis, but both options are ungrammatical as shown below.

\section{Attributive Subcomparative}

*John-wa [ Mary-ga manga-o yonda ]-yori omosiroi shoosetu-o John-TOP [ Mary-NOM comic-ACC read ]-than interesting novel-ACC yonda

read

'*John read a more interesting novel than Mary read a comic'

a. *John-wa [ Mary-ga manga-o yonda omosirosa ]-yori John-TOP [ Mary-NOM comic-ACC read interestingness ]-than omosiroi shoosetu-o yonda interesting novel-ACC read '*John read a more interesting novel than the interestingness that Mary read a comic' 
b. *John-wa [ Mary-ga manga-o yonda shoosetu ]-yori omosiroi John-TOP [ Mary-NOM comic-ACC read novel ]-than interesting shoosetu-o yonda novel-ACC read

'*John read a more interesting novel than the novel that Mary read a comic'

In both cases, the ungrammaticality is due to the fact that the relative clause cannot properly modify the head noun. In particular, the ungrammaticality of (53b) stems from the structure of the relative clause where the patient role of yonda 'read' is already taken by another DP. As one might expect, by substituting a gap for the object manga-o in (53b), the sentence becomes grammatical as shown in (54a) below, and correspondingly, the clausal comparative in (54b) derived from (54a) by deleting the noun is grammatical with the expected meaning.

a. John-wa [ Mary-ga yonda shoosetu ]-yori omosiroi shoosetu-o John-TOP [ Mary-NOM read novel]-than interesting novel-ACC yonda

read

'John read a more interesting novel than the novel that Mary read'

b. John-wa [ Mary-ga yonda ]-yori omosiroi shoosetu-o yonda John-TOP [ Mary-NOM read]-than interesting novel-ACC read 'John read a more interesting novel than Mary read'

Amount subcomparatives, which are grammatical, are a particularly interesting case. Under my analysis, (55), repeated from (51), has two underlying phrasal comparatives in (55a) and (55b). Importantly, (55a) is grammatical.

\section{Amount Subcomparative}

Mary-wa [ John-ga manga-o yonda ]-yori takusan hon-o yonda Mary-TOP [ John-NOM comic-ACC read ]-than many book-ACC read

'Mary read more books than John read comics'

a. Mary-wa [ John-ga manga-o yonda ryoo ]-yori takusan Mary-TOP [ John-NOM comic-ACC read amount ]-than many hon-o yonda

book-ACC read

'Mary read more books than the amount that John read comics'

b. *Mary-wa [ John-ga manga-o yonda hon ]-yori takusan hon-o Mary-TOP [ John-NOM comic-ACC read book ]-than many book-ACC yonda

read

'*Mary read more books than the amount that the books that John read comics'

It is surprising that the complex nominal in (55a) is grammatical, given that the complex nominal in (53a) is not, despite the fact that their difference is only the head noun (i.e. 
ryoo 'amount' vs. omosirosa 'interestingness'). I cannot offer a theoretical explanation for this contrast, but what is crucial here is that the judgments of clausal comparatives are exactly parallel to the judgments of the underlying phrasal comparatives that my analysis assigns them.

\subsection{Lack of specificity island effects}

A third difference between Japanese and English clausal comparatives has to do with the Specificity Island Constraint (SIC). ${ }^{28}$ It is well observed that extraction out of definite or specific noun phrases is illicit in English, as illustrated by (56) (Chomsky 1973, 1977; Fiengo 1987; Fiengo and Higginbotham 1981; Bowers 1988; Diesing 1992).
a. Who did you see pictures of?
b. *Who did you see the pictures of?
c. *Who did you see a certain picture of?

It is also known that this locality constraint restricts the possible scope of the comparative operator (Bresnan 1973; Kennedy and Merchant 2000). For instance, consider the following English clausal comparatives.

a. John bought a ring more expensive than Mary did

b. *John bought the ring more expensive than Mary did

c. *John bought a certain ring more expensive than Mary did

Interestingly, Japanese sentences analogous to (57a) and (57b) are perfectly grammatical, as shown in (58).

a. John-wa [ Mary-ga katta ]-yori takai yubiwa-o katta John-TOP [ Mary-NOM bought ]-than expensive ring-ACC bought

'John bought a ring more expensive than Mary did'

b. John-wa sono [ Mary-ga katta ]-yori takai yubiwa-o katta John-TOP that [ Mary-NOM bought]-than expensive ring-ACC bought 'John bought that ring more expensive than the ring that Mary did'

Importantly, it is not the case that the SIC is inactive in Japanese. This is shown by the following phrasal comparatives.
a. John-wa [ Mary ]-yori takai yubiwa-o katta
John-TOP [ Mary ]-than expensive ring-ACC bought
'John bought a ring more expensive than Mary did'
b. *John-wa sono [ Mary ]-yori takai yubiwa-o katta
John-TOP that [ Mary ]-than expensive ring-ACC bought

\footnotetext{
28 To the best of my knowledge, the observations made in this subsection have not been discussed before. It should be remarked here that the data presented here suggests that degree operator movement is indeed available in Japanese, contrary to what is claimed by Beck et al. (2004). I will come back to this in Sect. 8.
} 
'(intended) John bought that ring more expensive than Mary did'

Both in English and Japanese, the SIC for the comparative operator is only violated when what is compared to the than phrase, e.g. John (59), is outside of the specific DP. Therefore, the following phrasal comparatives are fine in both languages, because what is compared is the specific DP itself.

(60) a. John bought the ring more expensive than this one

b. John-wa sono [ kore ]-yori takai yubiwa-o katta

John-TOP that [ this ]-than expensive ring-ACC bought

'John bought that ring more expensive than this one'

Under my account, the grammaticality of (58b) is expected, since it has a grammatical underlying structure where the complement of yori denotes a ring that Mary bought, i.e. (61).

(61) John-wa sono [ Mary-ga katta yubiwa ]-yori takai yubiwa-o

John-TOP that [ Mary-NOM bought ring ]-than expensive ring-ACC

katta

bought

'John bought that ring more expensive than the ring that Mary did'

As the English translation of (61) indicates, such a phrasal comparative is fine in English as well. These sentences are parallel in structure to the grammatical sentences in (60).

\section{Constraints on head noun deletion}

I have so far shown how my account explains various empirical facts, some of which are unnoticed in the previous literature. In this section, I will discuss some overgeneration problems for my account, and postulate constraints on the deletion operations.

\subsection{A morphological constraint}

Let us start with an example that exhibits the so-called Negative Island Effect, previously discussed in particular by Beck et al. (2004), Oda (2008), and Shimoyama (2012). It is observed that (62) is infelicitous to the same extent as its English translation.

(62) ?*John-wa [ Mary-ga yatow-anak-atta ]-yori kasikoi hito-o mituketa John-TOP [ Mary-NOM hire-NEG-PAST ]-than smart person-ACC found '*John found a smarter person than Mary did not hire'

Under the account of the present paper, the following two underlying structures are available for (62), but the one with a non-degree nominal hito 'person' in (63b) is felicitous, and therefore (62) is predicted to be acceptable, contrary to fact. 
a. *John-wa [ Mary-ga yatow-anak-atta kasikosa ]-yori kasikoi John-TOP [ Mary-NOM hire-NEG-PAST smartness ]-than smart hito-o mituketa person-ACC found

'(lit.) John found a smarter person than the smartness that Mary did not hire'

b. John-wa [ Mary-ga yatow-anak-atta hito ]-yori kasikoi

John-TOP [ Mary-NOM hire-NEG-PAST person ]-than smart

hito-o mituketa

person-ACC found

'John found a smarter person than the person that Mary did not hire'

Thus, (62) is wrongly predicted to be felicitous, and more generally it is expected that the Negative Island Effect should not be observed for attributive comparatives in Japanese.

In order to solve this problem, I propose the following refinement to the theory. ${ }^{29}$

(64) Deletion of non-degree nouns in Japanese comparatives is licensed only if the embedded predicate is morphologically a verb.

In Japanese, the negative morphology -na- is a suffix that takes a verbal root and turns the entire verbal complex into an adjective for the purposes of inflection. I claim that due to the above constraint, the infelicitous sentence (62) cannot be derived from the sentence in (63b), because the embedded predicate is not morphologically a verb.

Although this constraint might at first blush look arbitrary, further empirical support for it comes from the fact that (62) becomes grammatical, if the embedded clause is further embedded by another clause where the main predicate is verbal, as shown in $(65) .^{30}$

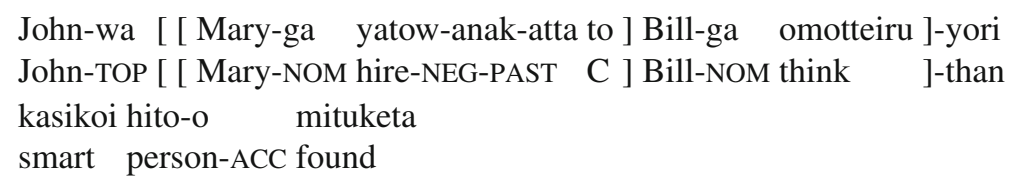

John-wa [ [ Mary-ga yatow-anak-atta to ] Bill-ga omotteiru ]-yori John-TOP [ [ Mary-NOM hire-NEG-PAST C ] Bill-NOM think ]-than kasikoi hito-o mituketa smart person-ACC found

'John found a smarter person than the person that Bill thinks Mary did not hire'

The main predicate of the embedded clause in (65), omotteiru, is a verbal predicate, and the sentence is acceptable in the indicated meaning. Supplemented with the constraint

\footnotetext{
29 A morphological condition of this sort on ellipsis is not unknown elsewhere. Although the proposed noun deletion cannot be completely likened to English VP-ellipsis due to its tighter distribution discussed below, VP-ellipsis is known to have a morphological constraint reminiscent in nature to (64). More specifically, it is not licensed when the preceding auxiliary has -ing (Johnson 2001; Sag 1976).
}

(i) a. *Doc Golightly is being discussed, and Sally is being $\Delta$ too.

b. *I remember Doc being discussed, but you recall Sally being $\Delta$.

(Johnson 2001, p. 442)

30 I thank an anonymous reviewer and Danny Fox (p.c.) for bringing this prediction to my attention. 
on deletion, my account can explain this amelioration effect. That is, (65), unlike (62), has a grammatical underlying phrasal comparative, namely (66a), although the other underlying sentence in (66b) is still unacceptable for independent reasons. ${ }^{31}$

a. John-wa [ [ Mary-ga yatow-anak-atta to ] Bill-ga omotteiru hito John-TOP [ [ Mary-NOM hire-NEG-PAST C ] Bill-NOM think person ]-yori kasikoi hito-o mituketa ]-than smart person-ACC found

'John found a smarter person than the person that Bill thinks Mary did not hire'

b. *John-wa [ [ Mary-ga yatow-anak-atta to ] Bill-ga omotteiru John-TOP [ [ Mary-NOM hire-NEG-PAST C ] Bill-NOM think

kasikosa ]-yori kasikoi hito-o mituketa smartness ]-than smart person-ACC found

'*John found a smarter person than the smartness that Bill thinks Mary did not hire'

Furthermore, the constraint is appropriate not only for the Negative Island Effect, but also for other ungrammatical sentences where the main predicate of the embedded clause is non-verbal, but does not bear the negative suffix. For example, the following sentences where the embedded predicate is adjectival and the copula is - $d a$, respectively, are judged unacceptable.

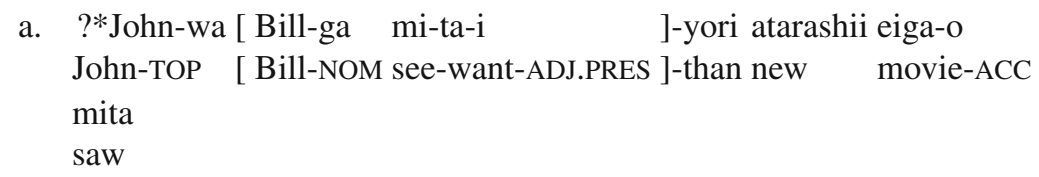

a. ?*John-wa [ Bill-ga mi-ta-i ]-yori atarashii eiga-o John-TOP [ Bill-NOM see-want-ADJ.PRES ]-than new movie-ACC mita saw

'(intended) John watched a newer movie than the one that Bill wants to see'

\footnotetext{
31 An anonymous reviewer pointed out that the following sentence involving a degree noun is relatively acceptable.

(i) ?John-wa [ daremo kaw-anak-atta takasa ]-yori takai hon-o katta John-TOP [ nobody buy-NEG-PAST expensiveness ]-than expensive book-ACC bought

'(lit.) John bought a more expensive book than the expensiveness that nobody bought'

The same reviewer also observes that the clausal analogue has a murky grammaticality compared to (62). Although the reviewer reports different judgments for these two sentences, they seem to me to have roughly the same acceptability. If my judgments are correct, this pair of sentences supports my analysis. However as the relevant judgments are arguably extremely subtle, I tentatively take these data as indecisive.

Also another reviewer reports that if the noun nedan 'price' is used in place of takasa 'expensiveness', (i) will sound far better to them, while the corresponding clausal comparative is still unacceptable. I do not fully agree with their judgments, but independently of its grammatical status, this version of the example involves one additional layer of complexity, as it is not clear whether nedan 'price' should be conceived of as a degree noun that can be deleted in relation to takai 'expensive'.
} 
b. *John-wa [ Bill-ga suki-na ]-yori kasikoi onnanoko-ni John-TOP [ Bill-NOM like-COP.PRES ]-than smart girl-DAT kisushita

kissed '(intended) John kissed a girl smarter than the girl that Bill likes'

My account attributes the infelicity of these sentences to the following admissible source structures, which are also infelicitous.

$$
\begin{aligned}
& \text { a.?*John-wa [ Bill-ga mi-ta-i atarasisa ]-yori atarashii } \\
& \text { John-TOP [ Bill-NOM see-want-ADJ.PRES newness ]-than new } \\
& \text { eiga-o mita } \\
& \text { movie-ACC saw }
\end{aligned}
$$

'(lit.) John watched a movie newer than the newness that Bill wants to see'

b. *John-wa [ Bill-ga suki-na kasikosa ]-yori kasikoi

John-TOP [ Bill-NOM like-COP.PRES smartness ]-than smart onnanoko-ni kisushita

girl-DAT kissed

'(lit.) John kissed a girl smarter than the smartness that Bill likes'

Crucially, the following felicitous phrasal comparatives in (69) cannot feed the deletion of the head noun to yield the sentences in (67), due to the morphological constraint (64) above.

$$
\begin{aligned}
& \text { a. John-wa [ Bill-ga mi-ta-i eiga ]-yori atarashii } \\
& \text { John-TOP [ Bill-NOM see-want-ADJ.PRES movie ]-than new } \\
& \text { eiga-o mita } \\
& \text { movie-ACC saw }
\end{aligned}
$$

'John watched a movie newer than the movie that Bill wants to see'

b. John-wa [ Bill-ga suki-na onnanoko]-yori kasikoi

John-TOP [ Bill-NOM like-COP.PRES girl ]-than smart

onnanoko-ni kisushita

girl-DAT kissed

'John kissed a girl smarter than the girl that Bill likes'

Also, the judgments of the sentences in (66) are expected to ameliorate if a verbal suffix is added. This prediction is borne out as shown in (70), where a verbal suffix -gatteiru is added to (66a). ${ }^{32}$

$$
\begin{aligned}
& \text { John-wa [ Bill-ga mi-ta-gatteiru ]-yori atarashii eiga-o mita } \\
& \text { John-TOP [ Bill-NOM see-want-seem ]-than new movie-ACC saw } \\
& \text { 'John watched a movie a newer movie than the one that Bill seems to want to } \\
& \text { see' }
\end{aligned}
$$

\footnotetext{
32 I thank Norvin Richards (p.c.) for raising this example. As an anonymous reviewer pointed out to me independently, the amelioration effects are observed with embedding under verbs like omotteiru 'is thinking', as expected. Also, the same point can of course be made with (66b), but the data is omitted here.
} 
It should be remarked here that the stativity of the embedded predicate is not what is at stage, as shown by the following examples.

a. ?*John-wa [ Bill-ga minogas-anak-atta ]-yori omoshiroi

John-TOP [ Bill-NOM miss-NEG-ADJ.PAST ]-than interesting

bangumi-o mita

TV.show-ACC watched

'(intended) John watched a more interesting TV show than the one that Bill did not miss'

b. MIT-ni-wa [ Harvard-ni i-ru ]-yori senotakai gakusei-ga

MIT-at-TOP [ Harvard-at exist-VERB.PRES ]-than tall student-NOM iru

exist

'There are taller students at MIT than at Harvard'

The embedded predicate in (71a) is eventive, but the example is still ungrammatical, as it involves an adjectival suffix -na-. Conversely, (71b) is grammatical despite the fact that the embedded predicate is a stative verb. The main predicate $i$ - here is morphologically a verb.

It should be stressed that the morphological restriction in question does not apply to deletion of degree nominals. As expected under this assumption, the example repeated in (72) is grammatical even though the embedded predicate is the copula and hence non-verbal.

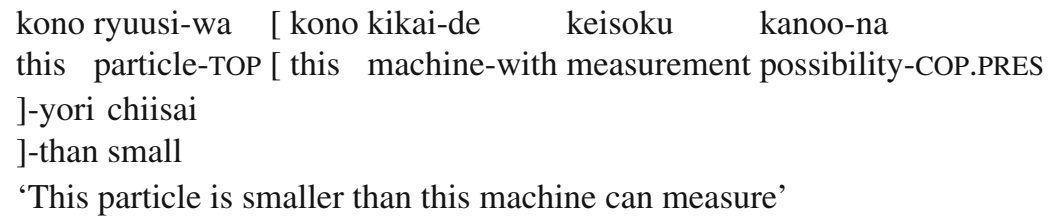

'This particle is smaller than this machine can measure'

For (72), the following source structure is available, where the head of the complex nominal is a degree nominal ookisa 'size'.

$$
\begin{aligned}
& \text { kono ryuusi-wa [ kono kikai-de keisoku kanoo-na } \\
& \text { this particle-TOP [ this machine-with measurement possibility-COP.PRES } \\
& \text { ookisa ]-yori chiisai } \\
& \text { size ]-than small } \\
& \text { 'This particle is smaller than the size that this machine can measure' }
\end{aligned}
$$

What this implies is that the two types of head noun deletion should be thought of as separate syntactic processes that are subject to different (but potentially overlapping) sets of constraints. In what follows, I will argue that these deletion operations should be further constrained by two more syntactic restrictions. 


\subsection{Structural contraints on head noun deletion}

The present account crucially postulates two noun deletion operations that optionally take place, when the licensor and the licensee stand in structural relations schematically depicted in the following diagrams.

a.

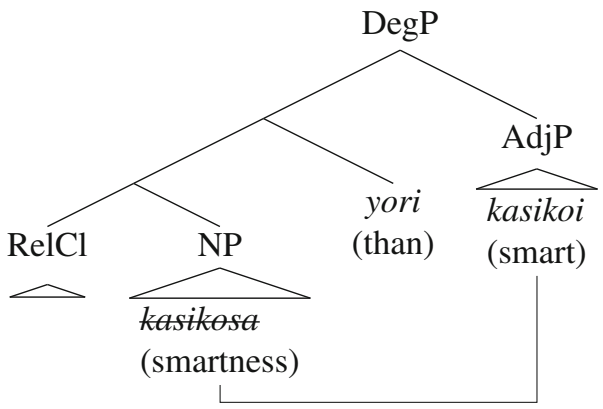

b.

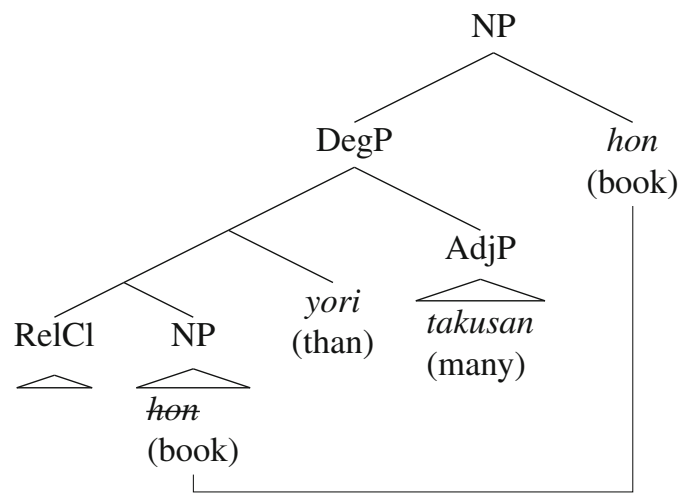

I assume that these structural relations are strictly necessary for deletion to be licensed. For example, head noun deletion is not licensed across sentences, unlike other ellipsis phenomena like VP-ellipsis and sluicing. ${ }^{33}$ More concretely, the mere presence of a licensor in a distinct sentence is not enough for the noun to go missing, as demonstrated by the ungrammatical sentences in (75). The purposed licensors are in bold face.

a. *John-wa totemo kasikoi ga, Mary-no kitaishita kasikesa de-wa John-TOP very smart but, Mary-GEN expected smartness COP-TOP nai

NEG

'(intended) John is very smart but does not have the smartness that Mary expected'

\footnotetext{
33 I thank an anonymous reviewer for pointing this out.
} 
b. *John-wa hon-o yom-anak-atta ga, Mary-wa Bill-ga kaita John-TOP book-ACC read-NEG-PAST but, Mary-TOP Bill-NOM wrote hon(-o) yonda book(-ACC) read '(intended) John didn't read a book, but Mary read a book that Bill wrote'

Without ellipsis, the sentences in (75) become grammatical under the respective intended readings.

Furthermore, the proposed noun deletion operations are not licensed even within the same sentence, if the licensor and the licensee do not stand in the structural configuration depicted in (74) above. ${ }^{34}$ For instance, compare the comparative sentences below.

a. kono beddo-wa [ Bill-ga omotta (nagasa) ]-yori nagai

this bed-TOP [ Bill-NOM thought (length) ]-than long

'This bed is longer than Bill thought'

b. kono nagai beddo-wa [ Bill-ga omotta ]-yori habagahiroi

this long bed-TOP [ Bill-NOM thought]-than wide

'This long bed is wider than Bill thought'

Not 'This long bed is wider than the length that Bill thought it had'

(76b) does not have the reading (77a), below, which it would have with an overt noun nagasa in the yori-phrase. Instead, the only available reading for it is the one that is synonymous with (77b) which involves the degree noun habahirosa 'width, wideness'.

a. kono nagai beddo-wa [ Bill-ga omotta nagasa ]-yori habagahiroi this long bed-TOP [ Bill-NOM thought length ]-than wide

'This long bed is wider than the length that Bill thought it had'

b. kono nagai beddo-wa [ Bill-ga omotta habahirosa ]-yori

this long bed-TOP [ Bill-NOM thought width ]-than

habagahiroi

wide

'This long bed is wider than Bill thought'

Thus the deletion of the degree noun nagasa 'length' is not licensed in (76b), unlike in (76a).

Similarly, the comparative sentence in (78b) is simply ungrammatical without an overt occurrence of the noun hon 'book' in the yori phrase, unlike (78a) where the two instances of hon 'book' stand in the relevant structural relation. This again shows that deletion of hon is not licensed outside of the configuration in (74).

a. John-wa [ Bill-ga kaita (hon) ]-yori omoshiroi hon-o kaita John-TOP [ Bill-NOM wrote (book) ]-than interesting book-ACC wrote 'John wrote a more interesting book than Bill wrote'

\footnotetext{
34 I thank an anonymous reviewer for bringing this fact to my attention.
} 
b. *kono hon-wa [ Bill-ga kaita hon ]-yori omoshiroi this book-TOP [ Bill-NOM wrote book ]-than interesting '(intended) This book is more interesting than the book that Bill wrote'

What we learn from the data above is that the deletion operations require certain structural relations between the licensor and the licensee, i.e. deletion is licensed within the local DegP, or in an attributive case, within the NP that the DegP modifies.

Furthermore, another structural constraint is additionally necessary to explain the fact that a relative clause is required for the head noun to be missing. Concretely, the following sentences are both ungrammatical with implicit nouns.
a. John-wa [ Bill-no *(senotakasa) ]-yori segatakai John-TOP [ Bill-GEN *(height) ]-than tall
'John is taller than Bill's height'
b. John-wa [ kono aoi *(hon) ]-yori omoshiroi hon-o yonda John-TOP [ this blue *(book) ]-than interesting book-ACC read 'John read a more interesting book than this blue book'

To sum up the discussion in this section, at least the following three constraints are necessary for my account to circumvent overgeneration.

a. Deletion of a non-degree noun is licensed only if the main predicate of the relative clause is morphologically verbal.

b. Deletion of a noun is licensed only under the structural configurations in (74).

c. Deletion of a noun is licensed only if there is a relative clause.

These constraints seem to be unrelated to each other, which might give an impression that the two deletion operations that my account crucially relies on lack theoretical motivation. However, I would like to stress the empirical adequacy of the proposed account. In the next section I will argue that it is in fact empirically superior to its predecessors, and none of them is capable of accounting for the range of observations made in the present paper.

\section{Previous theories and their problems}

As remarked in Sect. 1, the previous accounts of Japanese clausal comparatives can be broadly classified into two kinds: those that analyze Japanese clausal comparatives as underlyingly phrasal, just like the analysis advocated here (phrasal accounts; Beck et al. 2004; Oda 2008; Kennedy 2009), and those that admit underlyingly clausal structures as the complement of yori (clausal accounts; Kikuchi 1987; Ishii 1991; Snyder et al. 1994; Hoji 1998; Hayashishita 2009; Bhatt Takahashi 2011; Shimoyama 2012). ${ }^{35}$ In the present section, I review several previously proposed accounts of the

\footnotetext{
35 Ueyama (2004) also puts forward a phrasal analysis very similar in spirit to mine for most instances of clausal comparatives but, crucially, she does not deny the existence of genuinely clausal comparatives, unlike the present account. Some of my criticisms against clausal accounts apply to her analysis as well.
} 
syntax of Japanese clausal comparatives from both camps and point out their empirical problems. Especially, the data in (7) pose a serious challenge for them.

\subsection{Previous phrasal account: free relative account}

Beck et al. (2004) put forward a phrasal account where the embedded clauses in Japanese clausal comparatives are analyzed as relative clauses, but unlike the account of the present paper, they do not postulate a covert nominal head, and claim instead that the embedded clauses are free relatives that denote the maximal individual satisfying the predicate denoted by the relative clause. Although this naturally accounts for the parallelism with relative clauses discussed in Sect. 3, it has several empirical shortcomings. Below I will discuss two especially challenging ones.

First, as Beck et al. (2004) themselves acknowledge, Japanese does not have free relative constructions elsewhere. More concretely, Beck et al. (2004) analyze (81a) as a free relative synonymous with the English (81b), but such a relative clause should only be available as the complement of yori, and not in a simple sentence like (81c).
a. [ Mary-ga katta ]-yori
[ Mary-NOM bought ]-than
b. 'than what Mary bought'
c. *John-wa [ Mary-ga katta ]-ga hosii
John-TOP [ Mary-NOM bought ]-NOM want
'(intended) John wants what Mary bought'

To explain the limited distribution, Beck et al. hint at the possibility that free relatives in Japanese can only appear in comparative constructions for syntactic reasons. However, Shimoyama (2012) points out that this restriction is still insufficient, as the following comparative sentence is ungrammatical.
*kono hon-wa [ Hanako-ga yonda ]-yori takai
this book-TOP [ Hanako-NOM read]-than expensive
'(intended) This book is more expensive than what Hanako read'

Under Beck et al.'s analysis, (82) is predicted to be fine with the reading indicated above, contrary to fact. To make the matter worse, when the comparative gradable predicate is used attributively, the sentence becomes grammatical, as demonstrated by (83).
Taro-wa [ Hanako-ga yonda ]-yori takai hon-o yonda
Taro-TOP [ Hanako-NOM read ]-than expensive book read
'Taro read a more expensive book than Hanako did'

The contrast between the previous two sentences is of the same nature as the predicative vs. attributive contrast in (7). This problem of Beck et al.'s (2004) analysis stems from the fact that their analysis is strictly local and insensitive to the structure of the matrix clause, but as the data above suggests, the grammaticality of Japanese clausal comparatives is sensitive to the structure of the matrix clause. 
On the other hand, my account deploys a deletion operation that refers to the matrix structure and can capture the contrast in (7), as we saw in Sect. 2, and the sentences in (82) and (83) are accounted for in exactly the same manner. That is, (82) is correctly predicted to be ungrammatical, as the relative clause cannot modify the degree noun takasa 'expensiveness', as shown in (84), while (83) is predicted to be acceptable, as the relative clause can modify the non-degree nominal hon 'book', as in (85).

*kono hon-wa [ Hanako-ga yonda takasa ]-yori takai this book-TOP [ Hanako-NOM read expensiveness ]-than expensive

Taro-wa [ Hanako-ga yonda hon ]-yori takai hon-o yonda Taro-TOP [ Hanako-NOM read book ]-than expensive book read 'Taro read a more expensive book than the book that Hanako read'

A second problem for Beck et al. (2004) is that Japanese clausal comparatives can be gapless as shown in (51), which is repeated here.

$$
\begin{aligned}
& \text { Mary-wa [ John-ga manga-o yonda ]-yori takusan hon-o yonda } \\
& \text { Mary-TOP [ John-NOM comic-ACC read ]-than many book-ACC read } \\
& \text { 'Mary read more books than John read comics' }
\end{aligned}
$$

Being gapless, the complement of yori here cannot be a simple free relative. Beck et al. (2004) discuss this problem, and claim that they are actually Internally Headed Relative Clause (IHRCs). Following Shimoyama (1999), they assume that IHRCs are definite descriptions of some kind, and analyze the complement of yori in the above sentence as denoting the comics that John read.

However this analysis misses the generalization that gapless clausal comparatives in Japanese can only express amount comparison. For example, the following example where the comparative gradable predicate is nagai 'long' is ungrammatical.

$$
\begin{aligned}
& \text { *Mary-wa [ John-ga manga-o yonda ]-yori nagai hon-o yonda } \\
& \text { Mary-TOP [ John-NOM comic-ACC read ]-than long book-ACC read } \\
& \text { '(intended) Mary read a longer book than the comic that John read' }
\end{aligned}
$$

As the embedded clause here is identical to the one in (86), Beck et al.'s analysis makes the wrong prediction that (87) has the intended interpretation. Again, the problem consists in the localist nature of Beck et al.'s analysis where there is no way to make reference to the difference in the matrix structure.

On the other hand, my account is capable of this fact, as explained in Sect. 5. That is, a gapless degree nominal relative clause is only possible when the head noun is ryoo 'amount'.

\footnotetext{
a. John-ga manga-o yonda ryoo John-NOM comic-ACC read amount 'The amount of comics that John read'

b. *John-ga managa-o yonda nagasa John-NOM comic-ACC read length
} 


\subsection{Clausal accounts}

Let us now turn to clausal accounts. Clausal accounts of Japanese clausal comparatives allow the complement of yori to be clausal structures. This type of account has entertained more popularity in the literature, whose advocates include Kikuchi (1987), Hayashishita (2009), and Bhatt and Takahashi (2011). However, some of the data we have seen in the previous sections constitutes recalcitrant problems for clausal accounts.

First of all, for clausal accounts, the commonalities observed between relative clauses and clausal comparatives presented in Sect. 3 are not at all expected, and remain to be accounted for. I am aware of no clausal account that explicitly addresses this issue. Also a clausal account is required to explain the three properties of Japanese clausal comparatives presented in Sect. 5, but most of the studies cited above are not very explicit on this point either. Below, I examine Hayashishita's (2009) account in some detail, which is especially explicit about its predictions, and point out some empirical problems.

Hayashishita (2009) claims that the complement of yori may denote one of the following three kinds of semantic objects: (i) an individual, (ii) a degree and (iii) a proposition, the last of which is denoted by a clause. Furthermore, he claims that the semantic function of yori phrases is different from that of than phrases in English. More specifically, according to him, the standard of comparison in Japanese comparatives is pragmatically inferred from the complement of yori in the following manner.

$$
\begin{aligned}
& \text { 【yori } \rrbracket=\lambda s . \lambda P . \lambda x . \exists d: P(d)(x) \wedge d>f(s) \\
& \text { where } f \text { is a context-sensitive function from degrees, individuals and propo- } \\
& \text { sitions (depending on the type of } s \text { ) to degrees }
\end{aligned}
$$

(Hayashishita 2009, p. 87)

Also, in order to account for the ban on subcomparatives, Hayashishita additionally assumes that the complement of yori cannot contain a gradable predicate. This assumption explains the ban on simple comparatives, because the embedded predicate is a gradable predicate in this case too (cf. the morphological constraint proposed in Sect. 5).

Firstly, this additional morphological constraint is empirically too strong. For example, (90) is grammatical although the embedded predicate hoshii 'want' is gradable (and morphologically adjectival).

(90) John-wa [ Mary-ga hoshii ]-yori takusanno okane-o motteiru John-TOP [ Mary-NOM want ]-than much money-ACC have 'John has more money than Mary wants'

That hoshii is indeed a gradable predicate is shown by the following example demonstrating that it can be intensified.

$$
\begin{aligned}
& \text { Mary-wa okane-ga totemo hoshii } \\
& \text { Mary-TOP money-NOM very.much want } \\
& \text { 'Mary wants money very much' }
\end{aligned}
$$


Secondly, the contrast between predicative and attributive clausal comparatives observed in (7) cannot be given a straightforward account under this analysis. The relevant data is repeated here.
a. *John-wa [ Mary-ga yatotta ]-yori kasikoi
John-TOP [ Mary-NOM hired] ]-than smart
'(lit.) John is smarter than Mary hired'
b. John-wa [ Mary-ga yatotta ]-yori kasikoi hito-o mituketa John-TOP [ Mary-NOM hired] ]-than smart person-ACC found 'John found a smarter person than Mary hired'

The nature of the problem is the same as for the free relative account. That is, because it is predicted that the structure of the matrix clause is irrelevant for the well-formedness of clausal comparatives, it cannot predict the difference in grammaticality of the two sentences which only differ in the matrix structure. More specifically, Hayashishita (2009) would correctly predict that (14) is grammatical with a clausal complement to yori, but (7a) is wrongly predicted to be grammatical too.

\section{Crosslinguistic variation on the availability of clausal comparatives}

According to my phrasal account, Japanese lacks underlyingly clausal comparatives altogether, unlike English-type languages. In this section, I address the issue of crosslinguistic variation in comparative constructions, and develop an account of why Japanese lacks clausal comparatives but has phrasal ones. Before spelling out my own analysis, I will review two previous proposals about crosslinguistic variation that accompany two previous phrasal accounts, Beck et al. (2004) and Kennedy (2009).

\subsection{Degree abstraction parameter}

Recall that Beck et al. (2004) put forward a free relative account of Japanese clausal comparatives, whose empirical problems were discussed in the previous section. In order to account for the lack of clausal comparatives in Japanese, Beck et al. (2004, p. 325) postulate the following parameter.

Degree Abstraction Parameter (DAP)

A language $\{$ does, does not $\}$ have binding of degree variables in the syntax.

Following many studies of English comparatives, it is assumed that underlyingly clausal comparatives involve binding of degree variables in syntax, while underlyingly phrasal comparatives do not (cf. von Stechow 1984; Heim 1985; Bhatt and Takahashi 2011 and other works cited in fn. 6). Thus, if a language does not avail itself of degree binding in syntax, there is no way to form clausal comparatives.

Although this parameter is compatible with my account, it appears to be too strong. That is, there seem to be cases where degree binding configurations are required in Japanese. Here I present six such constructions, although none of them might be individually conclusive to show the inadequacy of the DAP. 
Firstly, wh-quantification over degrees is possible. ${ }^{36}$

\section{John-wa dore-kurai kasikoi no? \\ John-TOP which-degree smart Q \\ 'How smart is John?'}

Beck et al. (2004, p. 332) do mention degree questions like (93), and remark that this construction employs the noun kurai 'degree, extent'. They take this as suggesting that individual quantification, rather than degree quantification is involved here, and hence (93) is not a counterexample to the DAP. However, it seems to be tacitly assumed in their argument that nouns cannot denote degrees, but this lacks cogent motivation. In fact, what I have been calling degree nominals such as kasikosa 'smartness' and ryoo 'amount' are good candidates for nouns denoting degrees (or more strictly, predicates thereof), and so is kurai in (93). Notice in particular that what the question in (93) is asking is the degree to which John is smart, and is not a question about individuals. It is unclear how the semantics of (93) can be adequately analyzed with quantification over individuals.

Given these considerations, (93) can be taken to be evidence for binding of degree variables in syntax in Japanese. That is, (93) can be analyzed with the following schematic LF representation.

\section{which degree [ $\lambda d$ John is $d$-smart ]}

However, it should be admitted that this argument hinges on a potentially controversial assumption that Japanese wh-phrases involve wh-quantification in syntax, not only in semantics. In fact Shimoyama (2006) proposes a theory of Japanese wh-phrases with no explicit binding of variables in syntax. Therefore, depending on the correct theory of wh-phrases in Japanese, (94) may or may not be a problem for the DAP.

Secondly, we saw in Sect. 5 that Japanese phrasal comparatives obey the SIC. The relevant data is repeated here as (95).
a. John-wa [ Mary ]-yori takai yubiwa-o katta John-TOP [ Mary ]-than expensive ring-ACC bought 'John bought a ring more expensive than Mary did'
b. *John-wa sono [ Mary ]-yori takai yubiwa-o katta John-TOP that [ Mary ]-than expensive ring-ACC bought '(intended) John bought that ring more expensive than Mary did'

\footnotetext{
36 As an anonymous reviewer points out, the English translation for (93) is probably not accurate. To see this more concretely, consider the example below.

(i) John-wa dore-kurai segatakai no?

John-TOP which-degree tall Q

'How tall is John?'

First of all, (i) is evaluative unlike the English translation in the sense that it presupposes that John is tall. Also, I agree with the intuitions of the reviewer that most natural answers are probably not measure phrases like $180 \mathrm{~cm}$, but descriptions like He is very tall, although the former is not completely unacceptable. Fortunately, these details do not undermine the argument being made here.
} 
The same contrast is observed in both clausal and phrasal comparatives in English.

a. John bought $\{*$ the, a $\}$ ring more expensive than Mary

b. John bought $\{*$ the, a $\}$ ring more expensive than Mary did

These data are straightforwardly accounted for if there is movement of the comparative operator more. That is, assuming that the comparative operator needs to take scope right below what is compared in the matrix clause, e.g. John in (96), (cf. Bhatt and Takahashi 2011; Heim 1985), it needs to move out from the local DP, e.g. the object DP in (96). However, this movement is subject to the SIC, and hence the definite versions of (96) are ungrammatical. The Japanese examples in (95) are amenable to the same analysis. If this is on the right track, therefore, the comparative operator moves out of the local DP in Japanese as well, thereby creating a degree abstraction in syntax, which is in conflict with the DAP. ${ }^{37}$

Thirdly, as we repeatedly saw above, Japanese allows relative clause modification of degree nominals. A simple example is given in (97).

\section{[ Mary-ga manga-o yonda ] ryoo-wa 30-satu da [ Mary-NOM comic read ] amount 30-CL is '(lit.) the amount that Mary read comics is 30'}

Together with the assumption that ryoo 'amount' denotes a predicate of degrees, one could take this as showing that degree abstraction is indeed allowed in Japanese. For the sake of argument, let us assume an analysis of relative clauses under which they are assigned a predicative type $(\langle\sigma, t\rangle$ for some type $\sigma)$ and combine with a noun via a generalized conjunction ((Generalized) Predicate Modification; cf. Heim and Kratzer 1998). Then, the subject of (97) is assigned the LF representation schematically depicted in (98).

\section{(the) $[\lambda d$. Mary read $d$-many comics ] amount}

Here the noun amount is a predicate of degrees (of type $\langle d, t\rangle$ ), and so is the relative clause due to the lambda abstraction. These two predicates of type $\langle d, t\rangle$ combine via (Generalized) Predicate Modification, yielding another predicate of the same type. Then a covert definite article returns the maximal degree that this predicate is true of. Crucially, for this analysis to work, abstraction over degrees is necessary in syntax, contradicting the DAP. However, this argument crucially hinges on a particular theory of relative clauses, which has to be shown independently to hold for Japanese degree relative clauses, which to the best of my knowledge has not been done.

Fourthly, there are other degree constructions that seem to involve degree abstraction. One such construction is izyooni-comparatives discussed by Hayashishita (2007). ${ }^{38}$ They are comparative sentences expressing comparison of deviance from the contextually determined standard, unlike yori-comparatives which usually do not refer

\footnotetext{
37 It is predicted from this analysis that (95b) becomes grammatical if the complement of yori is changed to a degree phrase such as $\$ 5000$, which is correct.

38 Hayashishita (2007) also discusses gurai-equatives, which he argues require degree abstraction in the same way that yori-comparatives do, and thus the same point can be made with them.
} 
to the contextually determined standard. Interestingly, izyooni-comparatives allow predicative subcomparatives, unlike yori-comparatives, as demonstrated by (99).

$$
\begin{aligned}
& \text { John-wa [ beddo-ga nagai ]-izyooni segatakai } \\
& \text { John-TOP [ bed-NOM long ]-IZYOO tall } \\
& \text { 'John is taller than the bed is long (and the bed is long)' }
\end{aligned}
$$

Compare this to the yori-comparative construction in (100) which is ungrammatical.

$$
\begin{aligned}
& \text { (100) *John-wa [ beddo-ga nagai ]-yori segatakai } \\
& \text { John-TOP [ bed-NOM long ]-than tall } \\
& \text { '(intended) John is taller than the bed is long' }
\end{aligned}
$$

Crucially, (99) means that the difference between John's height and the standard height for people like John is greater than the difference between the bed's length and the standard length for a bed. This meaning requires the following kind of LF in the embedded clause, necessitating degree abstraction, as Hayashishita (2007) claims.

(101) [ $\lambda d$. the bed is $d$ longer than the standard length ]-izyooni

Similarly, Aihara (2009) claims that the superlative construction in Japanese requires degree abstraction. It is known that in English, a superlative sentence can receive two different interpretations. For example, (102) can be paraphrased in the following two different ways (Ross 1964; Szabolcsi 1986; Heim 1999). ${ }^{39}$

(102) John climbed the highest mountain

a. Comparative reading: Among the relevant climbers, John climbed a higher mountain than anybody else

b. Absolute reading: The mountain that John climbed is higher than any other relevant mountain

Interestingly, as Aihara (2009) observes, the superlative morpheme ichiban in Japanese can scramble and when it appears in front of the subject, it disallows one of the readings. Specifically, the sentence without scrambling in (103a) is ambiguous in the same way as the English sentence in (102) is, while (103b) with scrambling of ichiban only has the comparative reading in (102a).
a. John-ga ichiban takai yama-ni nobot-ta John-NOM most high mountain-to climb-PAST 'John climbed the highest mountain'
b. ichiban John-ga takai yama-ni nobot-ta most John-NOM high mountain-to climb-PAST 'John climbed the highest mountain'

(Aihara 2009, p. 347)

In order to account for this disambiguation effect, Aihara (2009) adopts the movement theory of superlatives proposed by Szabolcsi (1986) and Heim (1999) where the

\footnotetext{
39 The comparative reading requires a prosodic prominence on John for many speakers.
} 
difference between the two readings is attributed to the LF position of the superlative morpheme. For instance, the two readings of the English example in (102) are assigned the following LF structures.
a. Comparative Reading
John -est [ $\lambda d \lambda x x$ climbed a $d$-high mountain ]
b. Absolute Reading
John climbed the [ -est [ $\lambda d \lambda x x$ is a $d$-high mountain ] ]

The crucial assumption here is that the argument of - est that is of type $\langle d$, et $\rangle$ determines the relevant comparison class, i.e. the comparison class created from $f$ of type $\langle d, e t\rangle$ is $\{x$ : there is $d$ such that $f(d)(x)\}$. For the above examples, the comparison classes are the following.

a. Comparative Reading

$\{x$ : there is a degree $d$ such that $x$ climbed a $d$-high mountain $\}$

b. Absolute Reading

$\{x$ : there is a degree $d$ such that $x$ is a $d$-high mountain $\}$

Then, -est operates on the comparison class $C$ and yields the predicate of type $\langle e, t\rangle$ that takes an individual $x$ and states that there is a degree $d$ such that $f(d)(x)=1$ and for no alternatives $y$ of $x$ in $C, f(d)(y)=1$. $^{40}$ Assuming the same semantics for ichiban in Japanese, Aihara (2009) argues that the non-ambiguous sentence in (103b) obligatorily has an LF structure analogous to (104a). Crucially, this LF involves degree abstraction. Thus, if this analysis of Japanese superlatives is on the right track, the DAP is too strict. ${ }^{41}$

Another case that is potentially problematic for the DAP is the minimal requirement reading. Beck et al. (2004, p. 331) raise the example in (106a) to illustrate that Japanese comparatives do not license the reading that the English counterpart in (106b) has.

(106) (There is a 10 page long draft)

a. sono ronbun-wa sore yori tyoodo 5 peeji nagaku nakerebanaranai that paper-TOP that than exactly 5 page long be.required

b. That paper is required to be exactly 5 pages longer than that

One of the readings, probably the most prominent one, of the English sentence in (106b) is that in all situations compatible with the rules, the relevant paper is exactly 15 pages long. As observed by Heim (2000) among others, the same sentence also has a reading in which the relevant paper is allowed to be more than 15 pages long, which I call the minimal requirement reading. Contrary to (106b), the Japanese sentence in (106a) does not have this reading and the only available reading is the first reading where the requirement is that the paper be 15 pages long, not longer or shorter. Following

\footnotetext{
40 See Kotek et al. (2011) for a cross-categorical version of -est.

41 Incidentally, for Aihara, the absolute reading also requires the movement of ichiban, although the movement is within the local DP. This mirrors Heim's (1999) theory of English -est where this DP-internal movement is also necessary. This movement also requires degree abstraction in syntax and hence is incompatible with the DAP.
} 
Heim (2000), Beck et al. (2004) assume that the minimal requirement reading needs abstraction over degrees in syntax where exactly 5 pages longer than that takes scope over the modal, as schematically shown in (107) (see also Oda 2008).

[ [ exactly 5 pages -er than that ] [ $\lambda d$. that paper is required to be $d$-long ] ]

They argue that because this structure is not available in Japanese due to the DAP, the minimal requirement reading is unavailable for (106a).

I would like to point out here that the comparison between (106a) and (106b) is not enough to conclude that Japanese comparatives do not have the minimal requirement reading. The primary reason is because, as Heim (2000) observes, not all deontic modals license this reading in English either. For example, it is absent with must.

\section{(108) That paper must be exactly 5 pages longer than that}

Although it is beyond the scope of this paper to discuss the difference among deontic modals with respect to the availability of the minimal requirement reading (see Krasikova 2008; Beck 2010 for discussion), it is possible that the necessity modal in Japanese nakerebanaranai that Beck et al. (2004) employ in the above example happens to be one that does not license the minimal requirement reading. In fact, (109) where it is replaced with a different deontic modal does have the minimal requirement reading (see Shimoyama 2012 for related observations).

(109) sono ronbun-wa sore yori tyoodo 5 peeji nagai hitsuyoo-ga aru that paper-TOP that than exactly 5 page long need-NOM exist 'That paper needs to be exactly 5 pages longer than that'

On the assumption that the minimal requirement reading requires degree abstraction, as Beck et al. themselves assume, the availability of the minimal requirement reading in this example suggests that Japanese does have degree abstraction, contrary to the DAP. Even if this assumption is not correct, the data in (106a) is not necessarily showing that Japanese does not allow binding of degree variables in syntax.

To recapitulate, the DAP admittedly is an appealing parameter due to its strong predictive power, but in light of the above considerations, it seems to be too strong.

\subsection{Kennedy's semantic parameter}

Following Beck et al. (2004), Kennedy (2009) assumes the free relative account of Japanese clausal comparatives, and hence his analysis is a phrasal account, but he postulates a different parameter from Beck et al.'s (2004) DAP to account for the ban on clausal comparatives in Japanese. Specifically, his parameter is semantic in nature:

(110) a. Complex standards in Japanese are (only) type $e$

b. Complex standards in English are (potentially) type $d$

Just as Beck et al. (2004), Kennedy (2009) appears to be making the assumption that only clausal structures can denote degrees, and nominals cannot. From this assumption, 
it follows that Japanese does not have clausal comparatives, since they would denote degrees but yori cannot take a degree as its argument. In other words, under this account, semantics regulates what syntactic forms are allowed.

However, as already pointed out in the above discussion, the assumption that nominals cannot denote degrees is unwarranted. And it is clear that nominals denoting degrees can function as the complement of yori. ${ }^{42}$

$$
\begin{aligned}
& \text { John-wa [ } 180 \mathrm{~cm} \text { ]-yori segatakai } \\
& \text { John-TOP [ } 180 \mathrm{~cm} \text { ]-than tall } \\
& \text { 'John is taller than } 180 \mathrm{~cm} \text { ' }
\end{aligned}
$$

As in the following example, the complement of yori can also be a degree nominal such as John-no senotakasa 'John's height', which arguably denotes a degree.

$$
\begin{aligned}
& \text { kono ki-wa [ John-no senotakasa ]-yori ookii } \\
& \text { this tree-TOP [ John-GEN height ]-than big } \\
& \text { 'This tree is taller than John's height' }
\end{aligned}
$$

Given these data, Kennedy's parameter is empirically problematic.

\subsection{Morphosyntactic parameter}

Unlike the previous accounts discussed above, the new phrasal account advocated here allows for a purely morphosyntactic view of the crosslinguistic variation in comparative constructions. The idea is simple: the availability of underlyingly clausal comparatives depends solely on the morphosyntactic properties of the word for than that the language chooses to deploy. ${ }^{43}$

In Japanese, yori is morphologically a postposition, and indeed has a function outside of comparatives as a postposition marking the source (akin to from in English), although this use is slightly archaic. Crucially postpositions in this language generally can only combine with bare DPs and never with clausal complements. Given this morphosyntactic restriction on the combinatoric properties of postpositions, it is predicated that genuine clausal structures cannot appear as the complement of yori. In English, on the other hand, than does not have such a restriction.

Notice that this view does not necessarily predict that Japanese does not have clausal comparatives anywhere in its grammar, unlike Beck et al.'s (2004) and Kennedy's (2009) parameters. As a matter of fact, as remarked above, Hayashishita (2007) convincingly shows that the izyooni-comparative construction does allow underlyingly clausal comparatives. Under the present view, such variation within a single language

\footnotetext{
42 Beck et al. (2004) report that similar sentences receive an intermediate judgment, but I have not been able to replicate this with my informants, and in fact the majority of speakers accept such sentences. See also Hayashishita (2009) and Shimoyama (2012) for similar remarks.

43 A similar proposal is made by Bhatt and Takahashi (2011). I thank an anonymous reviewer for reminding me of this.
} 
should in principle be allowed. More specifically, the word izyooni can morphologically be decomposed into the noun izyoo and the postposition -ni, where the noun izyoo may combine with a relative clause, which has a clausal structure. ${ }^{44}$ As a consequence, izyoo, unlike yori, can directly combine with a relative clause, which has a clausal structure,

Of course, an extensive typological study is called for to validate the proposed claim, which is well beyond the scope of the present paper, but I would like to emphasize that this view does not require crosslinguistic variation in the semantics like Kennedy's semantic parameter, or parametrization at the syntax-semantics interface like the DAP, and thus allows us to entertain a more conservative view of variation where all sources of crosslinguistic variation are located in morphosyntax.

\section{Conclusions and a further problem}

To summarize, I proposed a novel syntactic account of Japanese clausal comparatives, which I claimed is empirically more adequate than its predecessors, especially with respect to the predicative vs. attributive contrast in (7), although the proposed noun deletion requires further theoretical scrutiny. Also I offered a new perspective on the crosslinguistic variation of comparative constructions where languages/constructions differ only in the morphosyntax and not in the semantics or the syntax-semantic interface.

Before closing this paper, I would like to mention one more property of Japanese clausal comparatives that has been extensively discussed in the literature. Since Ishii (1991), it is believed that there is a subtle contrast in acceptability between the following sentences (Beck et al. 2004; Kennedy 2009; Oda 2008; Snyder et al. 1994).

$$
\begin{aligned}
& \text { a. John-wa [ Mary-ga katta ]-yori takusanno kasa-o katta } \\
& \text { John-TOP [ Mary-NOM bought ]-than many umbrella-ACC bought } \\
& \text { 'John bought more umbrellas than Mary bought' } \\
& \text { b. ??John-wa [ Mary-ga katta ]-yori nagai kasa-o katta } \\
& \text { John-TOP [ Mary-NOM bought ]-than long umbrella-ACC bought } \\
& \text { 'John bought a longer umbrella than Mary bought' }
\end{aligned}
$$

The only difference between these sentences is the gradable predicate modified by the yori-phrase, namely, takusanno 'many' and nagai 'long'. This contrast is not expected under the account proposed in this paper, since in both cases, a grammatical non-degree source structure is predicted to be available, i.e. the sentences in (114).

\footnotetext{
44 The same applies to gurai which is used in the other construction that is shown in Hayashishita (2007) to allow for predicative subcomparatives.
} 


(114) a. John-wa [ Mary-ga katta kasa ]-yori takusanno
John-TOP [ Mary-NOM bought umbrella ]-than many
kasa-o katta
umbrella-ACC bought
'John bought more umbrellas than the umbrellas Mary bought'
b. John-wa [ Mary-ga katta kasa ]-yori nagai kasa-o
John-TOP [ Mary-NOM bought umbrella ]-than long umbrella-ACC
katta
bought
'John bought a longer umbrella than the umbrella Mary bought'

However I would like to question the validity of the empirical status of the contrast. As Snyder et al. (1994) and Beck et al. (2004) report, a considerable degree of interspeaker variation of the acceptability of (113b) is known, and in fact, for many native speakers, ${ }^{45}$ the contrast here appears to be very weak or almost unobservable.

Given the inter-speaker variation and the bluntness of the contrast, it is suggested in the literature (Beck et al. 2004; Hayashishita 2009) that this phenomenon is essentially pragmatic in nature. Beck et al. (2004, p. 301) remark as follows:

It seems to be a straightforward step to move from a set of objects to the number of things in that set. On the other hand, given a set of umbrellas, the step of inferring their maximal length is much less straightforward.

Based on this intuition, they claim that Japanese clausal comparatives are context sensitive unlike their English counterparts.

However, I think the relevant data should be examined more carefully before drawing a firm conclusion. That is, it would be no surprise if acceptability judgments were generally sensitive to pragmatic considerations such as what Beck et al. suggest in the above quote, and if so, a difference is expected under any account, including mine. Rather, in order to substantiate a claim like Beck et al.'s (2004) that the contrast demonstrates a distinctive property of Japanese comparatives, it needs to be shown that the contrast obtains more robustly with Japanese clausal comparatives than with some other constructions. This, to the best of my knowledge, has not been convincingly shown.

Thus I believe that the empirical status of Ishii's contrast is still quite nebulous. In particular, despite the apparent inter-speaker variation and the subtlety of the contrast, no quantitative study has been conducted. Given this nature of the issue and the lack of consensus on its empirical validity, I would like to refrain from taking a definitive view on this issue, and leave it as a potential problem for my account.

Acknowledgments I would like to thank three anonymous reviewers of Journal of East Asian Linguistics, whose comments, criticisms and suggestions greatly improved the quality of the paper. I am also indebted to many friends, colleagues and mentors at various stages of the research reported here, including: Adam Albright, Sigrid Beck, Rajesh Bhatt, Lisa Bylinina, Michael Y. Erlewine, Suzanne Flynn, Danny Fox, Irene Heim, Koji Kawahara, Toshiko Oda, David Pesetsky, Norvin Richards, Junko Shimoyama, Daeyoung Sohn, Shoichi Takahashi, Masaya Yoshida, Tomoyuki Yoshida, and Akira Watanabe. The detailed comments from

$\overline{45}$ This includes the author of this paper and about 15 native speakers informally consulted. 
Irene Heim, Danny Fox, David Pesetsky and Norvin Richards on an earlier version (written in 2009 as an unpublished Generals Paper at MIT) were especially helpful. Of course all the remaining errors are solely mine. An earlier version of this paper was presented at the 5th Workshop on Altaic Formal Linguistics (WAFL5) in 2008, and included in its proceedings as Sudo (2009). The proposal has been considerably revised since then.

Open Access This article is distributed under the terms of the Creative Commons Attribution License which permits any use, distribution, and reproduction in any medium, provided the original author(s) and the source are credited.

\section{References}

Abney, Steven. 1987. The English noun phrase in its sentential aspect. Ph.D. dissertation, Massachusetts Institute of Technology.

Aihara, Masahiko. 2009. The scope of -est: evidence from Japanese. Natural Language Semantics 17(4): 341-367. doi:10.1007/s11050-009-9046-6.

Beck, Sigrid. 2010. Quantifiers in than-clauses. Semantics \& Pragmatics 3(1): 1-72. doi:10.3765/sp.3.1.

Beck, Sigrid, Toshiko Oda, and Koji Sugisaki. 2004. Parametric variation in the semantics of comparison: Japanese vs. English. Journal of East Asian Linguistics 13: 289-344. doi:10.1007/ s10831-004-1289-0.

Bhatt, Rajesh, and Shoichi Takahashi. 2011. Reduced and unreduced phrasal comparatives. Natural Language and Linguistic Theory 29(3): 581-620. doi:10.1007/s11049-011-9137-1.

Bowers, John. 1988. Extended X-bar theory. In WCCFL 7, 47-62.

Bresnan, Joan. 1973. Syntax of the comparative clause construction in English. Linguistic Inquiry 4: 275343.

Büring, Daniel. 2007. Cross-polar nomalies. In Proceedings of SALT 17, 37-52.

Büring, Daniel. 2009. More or less. In Proceedings of Chicago Linguistic Society, 43.

Chomsky, Noam. 1973. Conditions on transformations. In A Festschrift for Morris Halle, eds. Stephen R. Anderson and Paul Kiparsky, 232-286. New York: Holt, Rinehart, and Winston, Inc.

Chomsky, Noam. 1977. On wh-movement. In Formal Syntax, eds. Peter Culicover, Thomas Wasow, and Adrian Akmajian, 71-132. New York: Academic Press.

Cresswell, Max J. 1976. The semantics of degree. In Montague Grammar, ed. Barbara H. Partee. New York: Academic Press.

Diesing, Molly. 1992. Indefinites. Cambridge, MA: MIT Press.

Fiengo, Robert. 1987. Definiteness, specificity, and familiarity. Linguistic Inquiry 18(1): 163-166.

Fiengo, Robert, and James Higginbotham. 1981. Opacity in NP. Linguistic Analysis 7: 395-421.

Fiengo, Robert, and Robert May. 1994. Indices and identity. Cambridge, MA: MIT Press.

Hackl, Martin. 2000. Comparative Quantifiers. Ph.D. dissertation, Massachusetts Institute of Technology.

Hankamer, Jorge. 1973. Why there are two than's in English. In Chicago Linguistic Society, vol. 9, eds. Claudia Corum, T. Cedric Smith-Stark, and Ann Weiser, 179-191. Chicago: Chicago Linguistic Society.

Harada, Shin-Ichi. 1971. Ga-no conversion and ideolectal variations in Japanese. Gengo Kenkyuu 60: 25-38.

Hardt, Daniel. 1993. Verb phrase ellipsis: Form, meaning, and processing. Ph.D. dissertation, University of Pennsylvania.

Hayashishita, J.R. 2007. Izyoo(ni)- and gurai-comparatives: Comparisons of deviation in Japanese. Gengo Kenkyuи 132: 77-109.

Hayashishita, J.R. 2009. Yori-comparative: Comments on Beck et al. (2004). Journal of East Asian Linguistics 18(2): 65-100. doi:10.1007/s10831-009-9040-5.

Heim, Irene. 1985. Notes on comparatives and related matters. ms., University of Texas, Austin.

Heim, Irene. 1999. Notes on superlatives. ms., Massachusetts Institute of Technology.

Heim, Irene. 2000. Degree operators and scope. In Proceedings of SALT 10, 40-64. Ithaca, NY: CLC Publications.

Heim, Irene. 2006. Remarks on comparative clauses as generalized quantifiers. ms., Massachusetts Institute of Technology.

Heim, Irene. 2008. Decomposing antonyms? In Proceedings of Sinn und Bedeutung 12, 212-225. Oslo: ILOS. 
Heim, Irene, and Angelika Kratzer. 1998. Semantics in generative grammar. Oxford: Blackwell.

Hiraiwa, Ken. 2002. Nominative-genitive conversion revisited. Japanese/Korean Linguistics 10: 546-559.

Hoeksema, Jack. 1983. Negative polarity and the comparative. Natural Language and Linguistic Theory 1 : 403-434.

Hoji, Hajime. 1998. Null object and sloppy identity in Japanese. Linguistic Inquiry 29: 127-152. doi:10. $1162 / 002438998553680$.

Ishii, Yasuo. 1991. Operators and empty categories in Japanese. Ph.D. dissertation, University of Connecticut, Storrs.

Johnson, Kyle. 2001. What VP-ellipsis can do, what it can't, but not why. In The handbook of contemporary syntactic theory, eds. Mark Baltin and Chris Collins, 439-479. Oxford: Blackwell.

Kaplan, Tamar I., and John B. Whitman. 1995. The category of relative clauses in Japanese, with reference to Korean. Journal of East Asian Linguistics 4(1): 29-58. doi:10.1007/BF01720745.

Kawahara, Koji. 2009. Standards of comparison in Japanese. In Proceedings of the 5th workshop on altaic in formal linguistics. Cambridge, MA: MIT Working Papers in Linguistics.

Kennedy, Christopher. 1999. Projecting the adjective: The syntax and semantics of gradability and comparison. New York: Garland Press.

Kennedy, Christopher. 2009. Modes of comparison. In Proceedings of Chicago Linguistic Society 43.

Kennedy, Christopher, and Jason Merchant. 2000. Attributive comparative deletion. Natural Language and Linguistic Theory 18(1): 89-146. doi:10.1023/A:1006362716348.

Kikuchi, Akira. 1987. Comparative deletion in Japanese. ms., Yamagata University.

Klein, Ewan. 1991. Comparatives. In Semantik: Ein internationales Handbuch der zeitgenössischen Forschung, eds. Arnim von Stechow and Dieter Wunderlich, 673-691. Berlin: Walter de Gruyter.

Kotek, Hadas, Yasutada Sudo, Edwin Howard, and Martin Hackl. 2011. Three readings of most. In Proceedings of SALT 21, 353-372.

Krasikova, Sveta. 2008. Quantifiers in comparatives. In Proceedings of SuB12, 337-352.

Lechner, Winfried. 2001. Reduced and phrasal comparatives. Natural Language and Linguistic Theory 19(4): 683-735. doi:10.1023/A:1013378908052.

Lechner, Winfried. 2004. Ellipsis in comparatives. Berlin: Mouton de Gruyter.

Lechner, Winfried. 2008. On binding scope and ellipsis scope. In Topics in Ellipsis, ed. Kyle Johnson, 154-182. Cambridge: Cambridge University Press.

Maki, Hideki, and Asako Uchibori. 2008. Ga/No conversion. In The Oxford handbook of japanese linguistics, eds. Shigeru Miyagawa and Mamoru Saito. Oxford: Oxford University Press.

Marantz, Alec. 2001. Words. Handout of the talk given at WCCFL 20.

Merchant, Jason. 2008. An asymmetry in voice mismatches in VP-ellipsis and pseudogapping. Linguistic Inquiry 39(1): 169-179. doi:10.1162/ling.2008.39.1.169.

Merchant, Jason. 2009. Phrasal and clausal comparatives in Greek and the abstractness of syntax. Journal of Greek Linguistics 9(1): 134-164. doi:10.1163/156658409X12500896406005.

Murasugi, Keiko. 1991. Noun phrases in Japanese and English: A study in syntax, learnability and acquisition. Ph.D. dissertation, University of Connecticut, Storrs.

Nambu, Satoshi. 2007. Reconsideration of ga/no conversion based on a quantitative analysis. Gengo Kenkyu 131: $115-149$.

Ochi, Masao. 2001. Move F and ga/no conversion in Japanese. Journal of East Asian Linguistics 10(3): 247-286. doi:10.1023/A:1011224313676.

Oda, Toshiko. 2008. Degree constructions in Japanese. Ph.D. dissertation, University of Connecticut, Storrs.

Ogawa, Yoshiki. 2004. The simple present tense in Japanese and the phonetically empty universal quantifier. Exploration in English Linguistics 19.

Pancheva, Roumyana. 2006. Phrasal and clausal comparatives in Slavic. In Proceedings of FASL 14, 236257.

Pancheva, Roumyana. 2007. Than. Paper presented at GLOW XXX, the University of Tromsø.

Pancheva, Roumyana. 2010. More students attended FASL than CONSOLE. In Formal Approaches to Slavic Linguistics 18: The Cornell Meeting, 2009, eds. W. Browne, A. Cooper, A. Fisher, E. Kesici, N. Predolac and D. Zec, 383-400. Ann Arbor: Michigan Slavic Publications.

Pinkal, Manfred. 1990. On the logical structure of comparatives. In Natural language and logic: Lecture notes in artificial intelligence, ed. R. Studer, 147-167. Berlin: Springer.

Ross, John. 1964. A partial grammar of English superlatives. MA thesis, Uniersity of Pennsylvania.

Rullmann, Hotze. 1995. Maximality in the semantics of Wh-constructions. Ph.D. dissertation, University of Massachusetts, Amherst. 
Sag, Ivan. 1976. Deletion and logical form. Ph.D. dissertation, Massachusetts Institute of Technology.

Shimoyama, Junko. 1999. Internally headed relative clauses in Japanese and E-type anaphora. Journal of East Asian Linguistics 8: 147-182. doi:10.1023/A:1008338020411.

Shimoyama, Junko. 2006. Indeterminate phrase quantification in Japanese. Natural Language Semantics 14(2): 139-173. doi:10.1007/s11050-006-0001-5.

Shimoyama, Junko. 2012. Reassessing crosslinguistic variation in clausal comparatives. Natural Language Semantics 20(1): 83-113. doi:10.1007/s11050-011-9076-8.

Snyder, William, Kenneth Wexler, and Dolon Das. 1994. The syntactic representation of degree and quantity: Perspectives from Japanese and Child English. In Proceedings of WCCFL 13, 581-596.

von Stechow, Arnim. 1984. Comparing semantic theories of comparison. Journal of Semantics 3: 1-77.

Sudo, Yasutada. 2009. Invisible degree nominals in Japanese clausal comparatives. In Proceedings of the 5th workshop on altaic in formal linguistics. Cambridge, MA: MIT Working Papers in Linguistics.

Szabolcsi, Anna. 1986. Comaprative superlatives. In Papers in theoretical linguistics, eds. Fukui Naoki, Tova Rapoport, and Elizabeth Sagey, 245-266. MIT Working Papers in Linguistics.

Ueyama, Ayumi. 2004. Nihongo no hikaku koobun ni tuiteno itikoosatu. Bungaku Kenkyuoku 101: 45-67.

Watanabe, Akira. 1996. Nominative-genitive conversion and agreemnet in Japanese: A cross-linguistic perspective. Journal of East Asian Linguistics 5(4): 373-410. doi:10.1007/BF00132699.

Watanabe, Akira. 2011. Adjectival inflection and the position of measure phrases. Linguistic Inquiry 42(3): 490-507. doi:10.1162/LING_a_00055.

Wunderlich, Dieter. 2001. Two comparatives. In Perspectives on semantics, pragmatics, and discourse: A Festschrift for Ferenc Kiefer, eds. István Kenesei and Robert M. Harnish, 75-91. Amsterdam: John Benjamins. 